Prepared in cooperation with Blaine County, Trout Unlimited, The Nature Conservancy, and the Wood River Land Trust

\title{
Aquatic Biological Communities and Associated Habitats at Selected Sites in the Big Wood River Watershed, South-Central Idaho, 2014
}

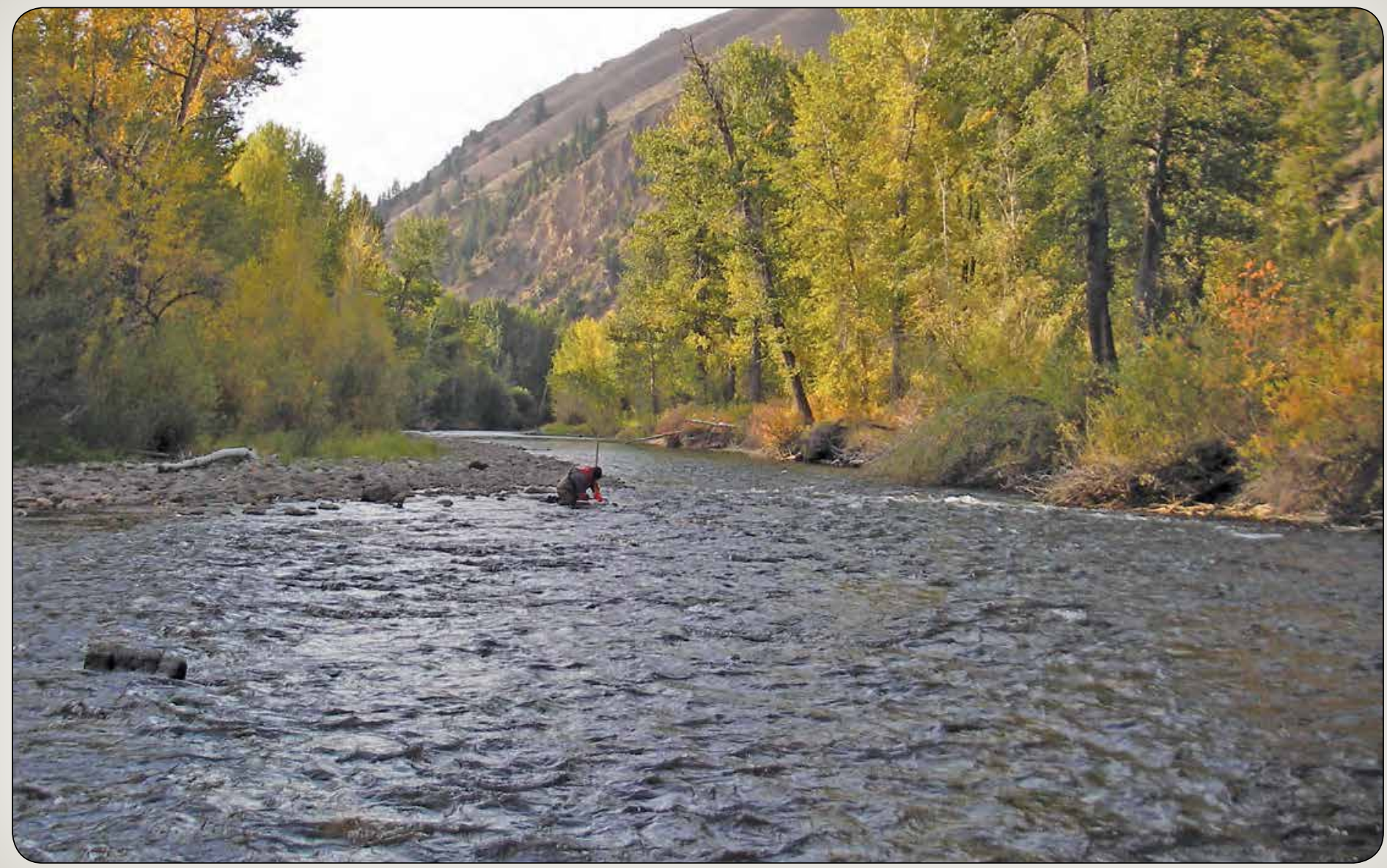

Scientific Investigations Report 2016-5128 
Cover: Big Wood River at Hailey, Idaho, looking downstream from the Bow Bridge with a scientist taking an invertebrate sample. Photograph by Dorene MacCoy, U.S. Geological Survey, September 17, 2014. 


\section{Aquatic Biological Communities and Associated Habitats at Selected Sites in the Big Wood River Watershed, South-Central Idaho, 2014}

By Dorene E. MacCoy and Terry M. Short

Prepared in cooperation with Blaine County, Trout Unlimited, The Nature Conservancy, and the Wood River Land Trust

Scientific Investigations Report 2016-5128 


\title{
U.S. Department of the Interior SALLY JEWELL, Secretary
}

\section{U.S. Geological Survey Suzette M. Kimball, Director}

\author{
U.S. Geological Survey, Reston, Virginia: 2016
}

For more information on the USGS - the Federal source for science about the Earth, its natural and living resources, natural hazards, and the environment-visit http://www.usgs.gov or call 1-888-ASK-USGS.

For an overview of USGS information products, including maps, imagery, and publications, visit http://store.usgs.gov.

Any use of trade, firm, or product names is for descriptive purposes only and does not imply endorsement by the U.S. Government.

Although this information product, for the most part, is in the public domain, it also may contain copyrighted materials as noted in the text. Permission to reproduce copyrighted items must be secured from the copyright owner.

Suggested citation:

MacCoy, D.E., and Short, T.M., 2016, Aquatic biological communities and associated habitats at selected sites in the Big Wood River watershed, south-central Idaho, 2014: U.S. Geological Survey Scientific Investigations Report 2016-5128, 37 p., http://dx.doi.org/10.3133/sir20165128.

ISSN 2328-0328 (online) 


\section{Contents}

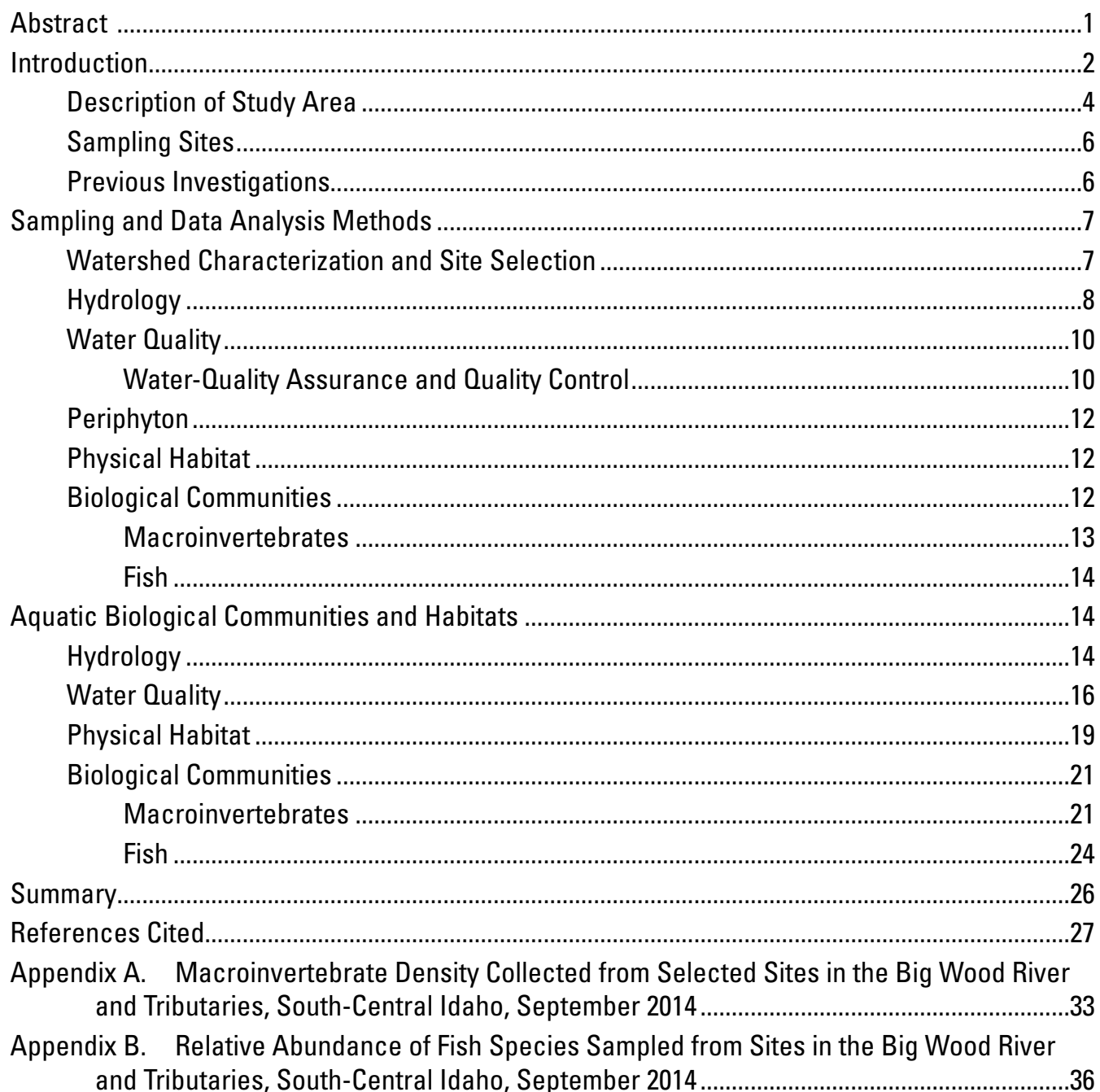




\section{Figures}

1. Map showing major populated areas and water-quality and biological sampling sites, Big Wood River watershed, south-central Idaho, 2014. 3

2. Graphs showing discharge and long-term median daily discharge for main-stem sites on the Big Wood River, south-central Idaho, water year 2014

3. Photograph showing assembly of 0 nset $^{\circledR}$ TidbiT $^{\circledR}$ thermistors to be attached to streamgage orifice line

4. Graph showing base-flow index values for selected sampling sites in the Big Wood River and tributaries, south-central Idaho, August 2014.

5. Graph showing continuous temperature for main-stem sites on the Big Wood River, south-central Idaho, May-September 2014.

6. Graph showing ephemeroptera, plecoptera, and trichoptera (EPT) taxa richness from samples collected at selected sites in the Big Wood River watershed, south-central Idaho, September 2014

7. Graphs showing temperature, suspended sediment, and nutrient tolerance values for invertebrates at selected sites, Big Wood River, south-central Idaho.

8. Graphs showing trout and Wood River sculpin (Cottus leiopomus) relative abundance from samples collected at sites in the Big Wood River watershed, south-central Idaho, September 2014

9. Photograph showing Wood River sculpin (Cotus leiopomus)

\section{Tables}

1. Watershed and site characteristics of Big Wood River, south-central, Idaho .5

2. Hydrologic measures used to characterize the flow regime for selected sites in the Big Wood River watershed, south-central Idaho, water years 2012-15.

3. Instantaneous water-quality and periphyton data collected from sampling sites in the Big Wood River watershed, south-central Idaho, September 2014

4. Daily mean temperatures for selected sites in the Big Wood River watershed, south-central Idaho, June-September 2014

5. Habitat data collected at selected sites, Big Wood River watershed, south-central Idaho, September 2014

6. Macroinvertebrate metrics calculated from samples collected at selected sites in the Big Wood River watershed, south-central Idaho, September 2014. 


\section{Conversion Factors}

International System of Units to Inch/Pound

\begin{tabular}{lcl}
\hline \multicolumn{1}{c}{ Multiply } & By & \multicolumn{1}{c}{ To obtain } \\
\hline millimeter $(\mathrm{mm})$ & Length & \\
micrometer $(\mu \mathrm{m})$ & 0.03937 & inch (in.) \\
meter $(\mathrm{m})$ & 0.00004 & inch (in.) \\
kilometer $(\mathrm{km})$ & 3.2808 & foot $(\mathrm{ft})$ \\
\hline & 0.62137 & mile $(\mathrm{mi})$ \\
\hline square kilometer $\left(\mathrm{km}^{2}\right)$ & Area & \\
\hline & 0.38610 & square mile $\left(\mathrm{mi}^{2}\right)$ \\
\hline liter $(\mathrm{L})$ & Volume & gallon (gal) \\
milliliter $(\mathrm{mL})$ & 0.26417 & gallon (gal) \\
cubic meter $\left(\mathrm{m}^{3}\right)$ & 0.00026 & acre-foot $(\mathrm{acre}-\mathrm{ft})$ \\
\hline & 0.00081 & \\
\hline cubic meter per second $\left(\mathrm{m}^{3} / \mathrm{s}\right)$ & Flow rate & cubic foot per second $\left(\mathrm{ft}^{3} / \mathrm{s}\right)$ \\
\hline & 35.315 & ounce (oz) \\
\hline milligram $(\mathrm{mg})$ & Mass & \\
\hline
\end{tabular}

Temperature in degrees Celsius $\left({ }^{\circ} \mathrm{C}\right)$ may be converted to degrees Fahrenheit $\left({ }^{\circ} \mathrm{F}\right)$ as follows:

$$
{ }^{\circ} \mathrm{F}=\left(1.8 \times{ }^{\circ} \mathrm{C}\right)+32 \text {. }
$$

\section{Datums}

Vertical coordinate information is referenced to the North American Vertical Datum of 1988 (NAVD 88).

Horizontal coordinate information is referenced to the North American Datum of 1983 (NAD 83).

Elevation, as used in this report, refers to distance above the vertical datum.

\section{Supplemental Information}

Specific conductance is given in microsiemens per centimeter at 25 degrees Celsius $\left(\mu \mathrm{S} / \mathrm{cm}\right.$ at $\left.25^{\circ} \mathrm{C}\right)$.

Concentrations of chemical constituents in water are given in either milligrams per liter (mg/L) or micrograms per liter $(\mu \mathrm{g} / \mathrm{L})$.

A water year is the 12-month period from October 1 through September 30 of the following calendar year. The water year is designated by the calendar year in which it ends. For example, water year 2013 is the period from October 1, 2012, through September 30, 2013. 


\section{Abbreviations}

$\begin{array}{ll}\text { AEP } & \text { annual expected probablility } \\ \text { BFD } & \text { bankfull discharge } \\ \text { BFI } & \text { baseflow index } \\ \text { BURP } & \text { beneficial use reconnaissance program } \\ \text { BW Hailey } & \text { Big Wood River at Hailey } \\ \text { BW Ketchum } & \text { Big Wood River near Ketchum } \\ \text { BW Stanton } & \text { Big Wood River at Stanton Crossing } \\ \text { CV } & \text { coefficient of variation } \\ \text { DMF } & \text { daily mean flow } \\ \text { East Fork } & \text { East Fork Big Wood River } \\ \text { EWI } & \text { equal width integrated } \\ \text { EPT } & \text { ephemeroptera, plecoptera, and tricoptera } \\ \text { FSBI } & \text { fine bed sediment index } \\ \text { IDAS } & \text { invertebrate data analysis system } \\ \text { IDEO } & \text { Idaho Department of Environmental Quality } \\ \text { IDFG } & \text { Idaho Department of Fish and Game } \\ \text { IDHW } & \text { Idaho Department of Health and Welfare } \\ \text { K } & \text { condition coefficient } \\ \text { MPN } & \text { most probable number } \\ \text { NAWQA } & \text { National Water-Quality Assessment } \\ \text { North Fork } & \text { North Fork Big Wood River } \\ \text { NWIS } & \text { National Water Information System } \\ \text { NWQL } & \text { National Water Quality Laboratory } \\ \text { PPBV } & \text { planes, plateaus, and broad valleys } \\ \text { RD } & \text { richness/density } \\ \text { RK } & \text { river kilometer } \\ \text { RPD } & \text { relative percent difference } \\ \text { SFI } & \text { stream fish index } \\ \text { SMI } & \text { stream macroinvertebrate index } \\ \text { SSC } & \text { suspended-sediment concentration } \\ \text { TMDL } & \text { total maximum daily load } \\ \text { Trail Ck } & \text { U.S. Environmental Protection Agency } \\ \text { EPA } & \text { W.S. Geological Survey } \\ \text { USGS } & \text { wetted volume } \\ \text { Warm Sp } & \text { WV treatment plant } \\ \text { WV } & \text { WWTP }\end{array}$




\title{
Aquatic Biological Communities and Associated Habitats at Selected Sites in the Big Wood River Watershed, South-Central Idaho, 2014
}

\author{
By Dorene E. MacCoy and Terry M. Short
}

\section{Abstract}

Assessments of streamflow (discharge) parameters, water quality, physical habitat, and biological communities were completed between May and September 2014 as part of a monitoring program in the Big Wood River watershed of south-central Idaho. The sampling was conducted by the U.S. Geological Survey in cooperation with Blaine County, Trout Unlimited, the Nature Conservancy, and the Wood River Land Trust to help identify the status of aquatic resources at selected locations in the watershed. Information in this report provides a basis with which to evaluate and monitor the long-term health of the Big Wood River and its major tributaries. Sampling sites were co-located with existing U.S. Geological Survey streamgaging stations: three on the main stem Big Wood River and four on the North Fork Big Wood River (North Fork), Warm Springs Creek (Warm Sp), Trail Creek (Trail Ck), and East Fork Big Wood River (East Fork) tributaries.

The analytical results and quality-assurance information for water quality, physical habitat, and biological community samples collected at study sites during 2 weeks in September 2014 are summarized. Water-quality data include concentrations of major nutrients, suspended sediment, dissolved oxygen, and fecal-coliform bacteria. To assess the potential effects of nutrient enrichment on algal growth, concentrations of periphyton biomass (chlorophyll- $a$ and ash free dry weight) in riffle habitats were determined at each site. Physical habitat parameters include stream channel morphology, habitat volume, instream structure, substrate composition, and riparian vegetative cover. Biological data include taxa richness, abundance, and stream-health indicator metrics for macroinvertebrate and fish communities. Statistical summaries of the water-quality, habitat, and biological data are provided along with discussion of how these findings relate to the health of aquatic resources in the Big Wood River watershed.

Seasonal discharge patterns using statistical summaries of daily discharge from selected sites are reported for water years 2012-15. Results showed that annual average daily mean discharge increased from the Big Wood River near Ketchum,
ID (BW Ketchum) downstream to the Big Wood River at Hailey, ID (BW Hailey), but decreased by nearly 50 percent from BW Hailey downstream to Big Wood River at Stanton Crossing near Bellevue, ID (BW Stanton). Annual variability in daily mean discharge among main-stem sites was highest at BW Stanton, suggesting that this part of the river may be subject to some level of flow alteration.

Hydrologic alterations resulting in flow reduction can contribute to higher water temperature, especially during the summer months when conditions are often most stressful to fish and other stream organisms. Daily water temperature and water temperature trends from June to September 2014 are reported for select tributary and main-stem sites on the Big Wood River and can be used to assess the potential for biological impairment based on aquatic life temperature criteria for cold-water streams. The State of Idaho maximum temperature criteria for protection of cold-water aquatic life of $22{ }^{\circ} \mathrm{C}$ was exceeded at Warm Sp and BW Stanton during summer 2014, but at none of the other main-stem or tributary sites. The $13{ }^{\circ} \mathrm{C}$ critical temperature criterion for salmonid spawning was exceeded in early July 2014 at BW Ketchum and BW Hailey near the end of the rainbow trout critical spawning and rearing period. Temperature exceedances were most frequent at BW Stanton, where exceedances for rainbow trout and brown trout occurred from May through early July 2014 during most of the critical spawning and rearing period.

Water quality and habitat availability did not seem to be limiting for fish or other aquatic organisms at most sites in the Big Wood River watershed. Water quality assessments in September 2014 determined no exceedances of total maximum daily load target levels. The availability and quality of habitat was limited at BW Stanton, where shallow-water habitat conditions prevailed.

Macroinvertebrate community diversity was high at all sites except for BW Stanton, where low community diversity was attributed to low species richness and high abundances of a few tolerant taxa. Presence of low species diversity and high macroinvertebrate tolerance values at BW Stanton indicates that benthic community condition and stream health were reduced at that location. 
Fish surveys done in September 2014 did not indicate any significant reductions in native fish communities in the Big Wood River or its tributaries. Native rainbow trout (Oncorhynchus mykiss) and Wood River sculpin (Cottus leiopomus) were the dominant fish species in the drainage and were found at all tributary and main-stem sites. Non-native brown (Salmo trutta) and brook trout (Salvelinus fontinalis) were limited to lower drainage sites on the Big Wood River (BW Hailey and BW Stanton), and occurred in relatively low numbers.

\section{Introduction}

The population of Blaine County in south-central Idaho nearly quadrupled from about 5,700 to 22,000 people between 1970 and 2010 (Forstall, 1995; U.S. Census Bureau, 2011). Residents and resource managers of the Big Wood River watershed (fig. 1) are concerned about how population growth may affect the quantity and quality of the groundwater and surface-water resources. Increased human activities and associated demands on existing water resources could alter the flow, water quality, habitat, and biological properties of streams, threatening the health of these systems in the watershed. The possibility that altering natural flow regimes and water-use practices (such as withdrawal for irrigation, public supply, and commercial use) can accentuate habitat loss for aquatic organisms is of concern, particularly for native fish species, which have relatively specific habitat requirements with respect to flow velocity, stream depth, and water temperature. For example, fishery studies in the $1980 \mathrm{~s}$ determined that altered stream reaches in the Big Wood River contained one-tenth of the trout densities that unaltered or "natural" reaches contained (Thurow, 1988).

Increased residential development along river corridors can decrease density of riparian vegetation and increase the amount of impervious surfaces that often lead to increased storm runoff and higher and more variable peak discharge. As frequency and intensity of peak flows increase, the likelihood of streambed scouring and channel incision increases. Furthermore, as riparian and adjacent areas become more developed, there is an increased potential for decreased infiltration to groundwater that can lead to diminished discharge during dry periods when groundwater is the main source of discharge.

An increase in other land-use activities in the watershed, such as agriculture, ranching, and logging, could potentially increase sediment and nutrient loading to receiving systems during periods of snowmelt or rainfall driven surface runoff events. For example, recent wildfires in the upper Big Wood River watershed resulted in loss of hillslope stability and increased debris flow and sediment input to the Big Wood River (Skinner, 2013). Nutrients and excess sediment loading to streams are a leading cause of water-quality and biological impairment in the Nation's streams (U.S. Environmental
Protection Agency, 2006). Sediment erosion from disturbed land surfaces and stream banks can increase turbidity which, when prolonged, can decrease the light penetration necessary for growth of important primary producers such as benthic algae. Additionally, turbid waters tend to absorb more heat from sunlight and can increase stream water temperatures (Waters, 1995). Sediment deposition can severely affect biological diversity by reducing the quality and quantity of stream-bottom habitat available to fish and other stream organisms. Similarly, excessive concentrations of nutrients resulting from local sources such as sewage outfalls, septic tanks, and livestock operations, or from more dispersed sources such as agriculture and associated fertilizer applications, are associated with altered biological communities in streams and rivers (U.S. Environmental Protection Agency, 2006; Dubrovsky and others, 2010). These land use practices and alteration of natural flow regimes in the watershed are a potential threat to the wellbeing of resident aquatic communities. Native species, such as the endemic Wood River sculpin (Cottus leiopomus), are particularly vulnerable to environmental change (Zaroban, 2010). This small fish is a protected nongame species that is vulnerable primarily because of its limited range, but is also threatened by declining stream health resulting from water-quality degradation, habitat loss, invasive predatory fish, floodplain encroachment, and flow alteration in the Big Wood River (Zaroban, 2010). Although associations between excess nutrients and macroinvertebrate and fish communities are often difficult to quantify, harmful effects can occur when elevated nutrients result in eutrophication. Problems with eutrophication in streams include the negative aesthetic effect of excessive algal growth, associated taste and odor problems, adverse biological effects from low dissolved oxygen and high $\mathrm{pH}$ (Dodds and Welch, 2000), and impediments to channel flows from dense growths of algae or aquatic macrophytes (Ferreira and others, 1999). However, these effects can vary in degree of severity from one stream to another as a result of differences in patterns of discharge, amount of riparian shading, water temperature, water clarity, and the extent of groundwater and surface water exchange (Dubrovsky and others, 2010; Riseng and others, 2011).

The Idaho Department of Environmental Quality (IDEQ) designated that beneficial uses of the Big Wood River and tributaries include supporting cold-water aquatic life, salmonid spawning, primary and secondary contact recreation, special resource waters, and domestic and agricultural water supply (Buhidar, 2002). Special resource waters outlined in Idaho Water-Quality Standards have special restrictions to protect cold water biota that include no detectable increase in ambient water temperature as a result of a flow alteration (Buhidar, 2002). The Big Wood River Management Plan identified the Big Wood River as not meeting standards because of high concentrations of suspended sediment, fine substrate sediment, total phosphorus, bacteria, and high water temperatures (Buhidar, 2002). 


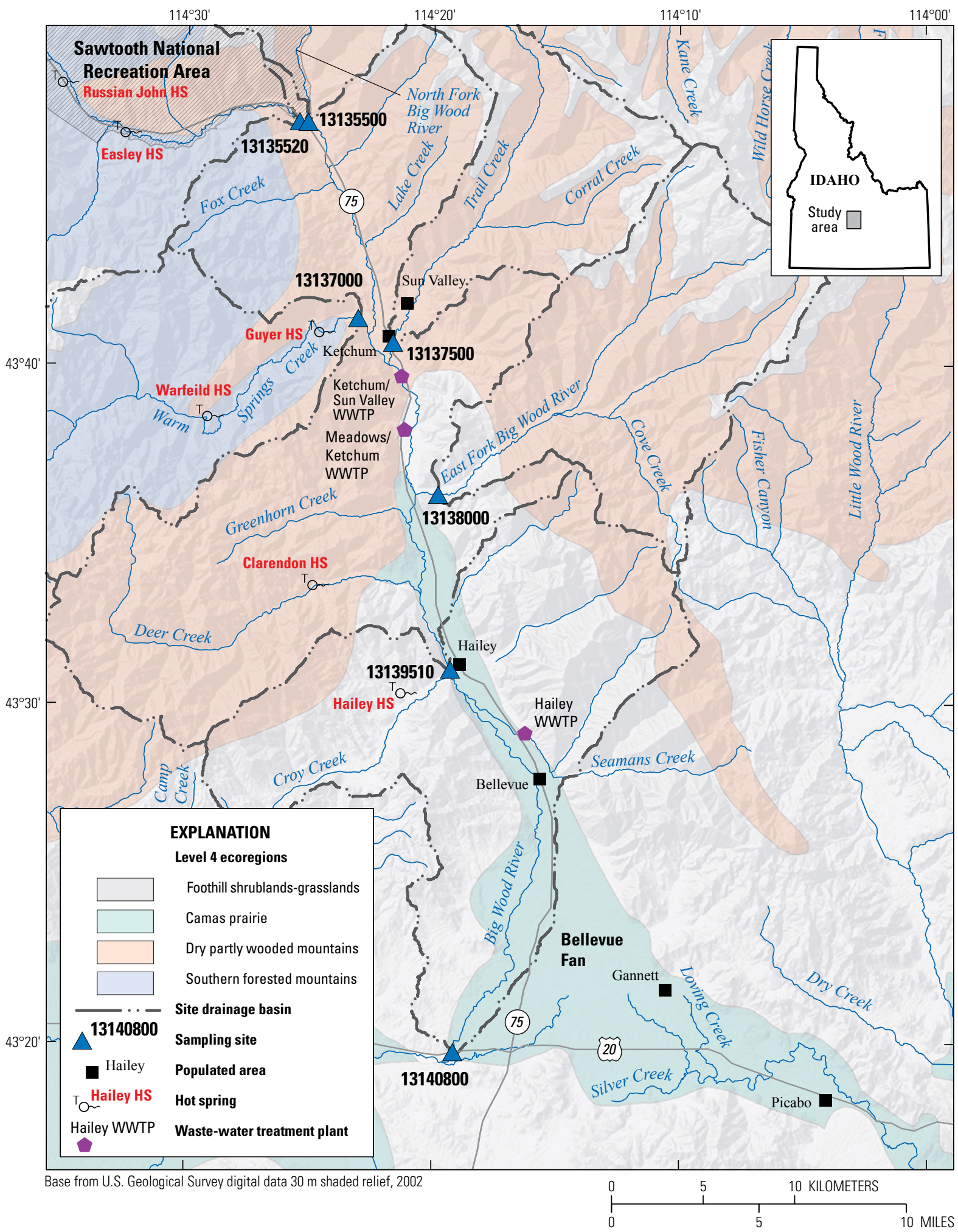

Figure 1. Major populated areas and water-quality and biological sampling sites, Big Wood River watershed, south-central Idaho, 2014. Names of numbered sites are shown in table 1. 
Stream degradation is rarely caused by a single factor, but is often the consequence of multiple physical, chemical, and biological factors interacting (Carlisle and others, 2013). Identifying the role of each of these factors in influencing ecosystem health poses a challenge to development of effective water-quality and biological management strategies. The ability of biological communities to integrate, over space and time, effects of multiple environmental stressors provides a mechanism with which to identify stressor effects from many sources. For example, algae, macroinvertebrate, and fish communities each represents a different functional role in the ecosystem, responds in different ways to human-caused environmental change, and thus provides different and complementary perspectives on water-quality and stream health. Collectively, these communities, along with key waterand habitat-quality parameters, provide a comprehensive basis of understanding with which to assess long-term effects of multiple environmental stressors on the quality of freshwater resources (Karr, 1991; Lapointe and others, 2014).

Despite concerns about the sustainability of the health of the Big Wood River, there is a lack of long-term waterand biological-quality monitoring in the watershed (Hopkins and Bartolino, 2013). The information in this report is intended to characterize selected discharge, water quality, physical habitat, and biological properties of the Big Wood River and its major tributaries, and to provide ecologically relevant guidelines to help in the design and implementation of long-term monitoring efforts in the Big Wood River watershed. Assessments of discharge, water quality, physical habitat, and biological communities were completed in September 2014 by the U.S. Geological Survey, in cooperation with Blaine County, Trout Unlimited, the Nature Conservancy, and the Wood River Land Trust. Samples were collected in September 2014 at three sites on main stem of the Big Wood River: Big Wood at Ketchum (BW Ketchum), Big Wood at Hailey (BW Hailey), and Big Wood at Stanton Crossing (BW Stanton). Samples also were collected at four major tributaries of the Big Wood River: North Fork Big Wood River (North Fork), Warm Springs Creek (Warm Sp), Trail Creek (Trail $\mathrm{Ck}$ ), and East Fork Big Wood River (East Fork). Sampling reaches were near existing U.S. Geological Survey (USGS) streamgaging stations where continuous daily discharge information was available. Daily discharge and associated hydrologic variables were calculated for water years 2012-15. Continuous daily water temperature was measured at each site during May-September 2014. Water-quality samples, habitat measurements, and biological samples were collected during 2 weeks in September 2014.

\section{Description of Study Area}

The Big Wood River watershed in south-central Idaho has a drainage area of approximately $3,800 \mathrm{~km}^{2}$ and consists of three ecoregions: the Southern Forested Mountains, the Dry Partly Wooded Mountains, and the Camas Prairie (Omernik and Griffith, 2008). The Big Wood River originates in a mountainous area of south-central Idaho at an elevation of about 3,300 $\mathrm{m}$ and transitions from primarily forest and alpine meadows in the higher elevations to sagebrush steppe at the lower elevations of about 1,500 m (fig. 1; McGrath and others, 2002; Tetra Tech, 2011). The climate is mild and arid during summer months, but cold and wet during winter, with about 60 percent of the total annual precipitation occurring between the first of November and the end of March, mostly as snow. The growing season varies in length, ranging from about 3 months in the cooler, high elevations near Ketchum to about 5 months in the lower watershed. The drought conditions during data collection in the Big Wood River watershed are categorized as moderate (U.S. Geological Survey, 2016a).

The upper and lower parts of the Big Wood River watershed in Blaine County differ in major land use (table 1). Most of the population growth, land development, and tourism occur in the northernmost part of the county near the communities of Sun Valley, Ketchum, Hailey, and Bellevue. This area is dominated by recreational areas popular for skiing, fishing, and other outdoor activities. Local resorts and numerous fly fishing guides provide services in the area that attract recreationists from around the world to the Big Wood River. The population of Blaine County depends on groundwater for domestic and public supply, either from privately-owned or municipal-supply wells (Hopkins and Bartolino, 2013). In contrast, irrigation for local agriculture is largely dependent on surface water supplies. Three wastewater-treatment plants (WWTP) discharge to the Big Wood River: the northernmost WWTP is located within the City of Ketchum (Ketchum/Sun Valley), one is located south of Ketchum (Meadows/Ketchum WWTP), and the WWTP farthest south in the watershed is located within the City of Hailey (Hailey WWTP, fig. 1). Additionally, many homes in the watershed are on septic systems that percolate into the Big Wood River Valley aquifer (Bartolino, 2009) and may have an impact on water quality.

The lower Big Wood River watershed downstream of Bellevue (Bellevue Fan) is primarily farms and ranches irrigated by groundwater and diverted surface water. Farmland irrigation began as early as 1900 (Jones, 1952) and has since expanded, with increased agricultural water needs within the watershed. Periodic changes in discharge for the Big Wood River, particularly in the downstream reaches, have been directly related to seasonal patterns of surface and groundwater withdrawal for irrigation (Hopkins and Bartolino, 2013). Water use for irrigation typically occurs during the growing season between May and September, during which time discharge in the southwestern part of the watershed is diminished and portions of the river downstream of Bellevue can go dry. 


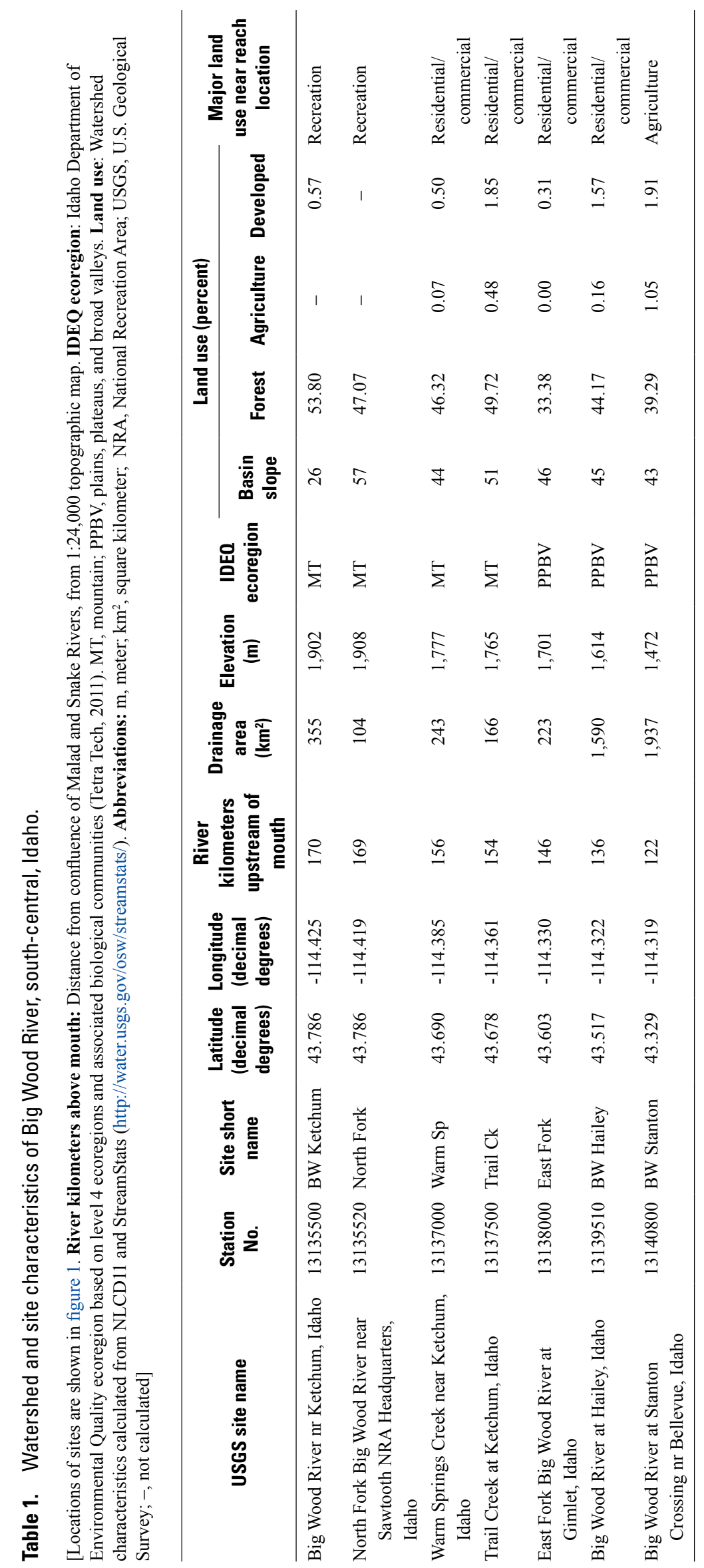




\section{Sampling Sites}

Locations of study sites on the Big Wood River main stem and major tributaries are shown in figure 1 and listed in table 1 . The northernmost study sites in the watershed are the BW Ketchum (13135500) at 170 river kilometers (RK) upstream of the mouth and on North Fork (13135520, RK 169). Both sites drain relatively undeveloped lands within the Sawtooth National Recreation Area managed by the U.S. Forest Service and are $16 \mathrm{~km}$ upstream of local population centers at Sun Valley and Ketchum. Two tributary sites are located within the city of Ketchum, Warm Sp (13137000, RK 156) and Trail Ck (13137500, RK 154). The Warm Sp drainage area contains the Guyer Hot Springs system located $3.2 \mathrm{~km}$ upstream of the sampling site (Foley and Street, 1988). This geothermal system provides heating to local residences and mixes with colder groundwater and surface water prior to discharging to Warm Springs Creek. A 1986 study by the U.S. Environmental Protection Agency (EPA) indicated that the geothermal waters from this system did not substantially increase the overall water temperature of Warm Springs Creek (Renk, 1986). Land use bordering these tributary sites is primarily light residential and commercial. Recently, increased surface runoff and soil erosion as a consequence of the 2013 Beaver Creek fire (Skinner, 2013) resulted in increased sediment loading to the upper and middle parts of Warm Springs Creek prior to the 2014 sampling. The East Fork (13138000, RK 146) discharges to the Big Wood River main stem downstream of the town of Ketchum. The East Fork headwaters originate on land managed by the Bureau of Land Management that has a history of mining activity (Hopkins and Bartolino, 2013). The East Fork sampling site is located in a rural area dominated by small ranches. The BW Hailey study site (13139510, RK 136) is located within the City of Hailey at the USGS streamgaging station that has been in operation since 1916. The farthest downstream sampling site, BW Stanton (13140800, RK 122), is in the western Bellevue Fan area that drains about $1,900 \mathrm{~km}^{2}$. Discharges at this site typically decrease in the summer months owing to upstream surface water diversions for pasture and crop irrigation.

\section{Previous Investigations}

Effects of altered discharge on water quality and quantity in the Big Wood River watershed have been documented, but studies targeting long-term trends in water quality and biological condition are lacking. The importance of long-term monitoring to assessing the health of streams and rivers in the Big Wood River watershed was recognized more than 60 years ago by Jones (1952, p. 1), who concluded that "records covering a period of many years are necessary to evaluate adequately the effect of vagaries of the weather and to determine the safe yield during drought periods." Referenced here is a list of environmental studies for streams and rivers in the Big Wood River watershed.
- Urbanization effects on water resources in the Big Wood River watershed were investigated by the Idaho Department of Water Resources in 1975 (Castelin and Chapman, 1972). That study attributed increased water use and water-quality degradation in the Big Wood River valley to increased urban development and included mining and agriculture as contributing sources of pollution. The report includes historical records of early fisheries and provides accounts of large trout being caught in the Big Wood River as far back as 1877 and the stocking of rainbow (Oncorhynchus mykiss) and eastern brook (Salvelinus fontinalis) trout in the watershed as early as 1912.

- Thurow (1988) determined that trout densities in the Big Wood River were positively correlated with the amount of available fish habitat cover and that reaches with altered habitat conditions contained one-tenth of the trout densities than undisturbed or "natural" reaches contained. Based on these findings, the author suggested that restoration of fish habitat was needed throughout the Big Wood River watershed.

- Maret and others (1997) studied fish assemblages and habitat conditions for a number of relatively undisturbed streams in the Upper Snake River watershed that included sites on the Big Wood River. The authors concluded that the major environmental factors determining fish distributions were stream gradient, watershed size, connectivity, and percentage of watershed covered by forest. Fish community properties that varied the greatest among sites were total number of species, number of native species, number of salmonid species, and percentages of introduced species, cottidae, and salmonids. Least-disturbed streams tended to have fewer fish species than sites affected by human activities, where tolerant species have been introduced. The study also concluded that there was a distinct difference in composition of fish communities between spring-fed and non-spring fed stream systems in the Big Wood River watershed, which they attributed in part to differences in habitat.

- Maret and others (2001) and Hardy and others (2005) summarized water-quality conditions and macroinvertebrate community composition for a number of Idaho streams and rivers and included sites in the Big Wood River watershed - the BW Stanton and Silver Creek near Sportsman Access. The reports concluded that biological conditions at both sites were indicative of healthy stream environments with relatively unimpaired water quality. Idaho bioassessment data published in Maret and others (2001) and subsequent samples collected as part of a statewide water-quality network between 1998 
and 2008 are available in at U.S. Geological Survey (2016b) or U.S. Geological Survey (2016c).

- Since 1993, the IDEQ Beneficial Use Reconnaissance Program (BURP; Idaho Department of Environmental Quality, 2016) has collected biological and habitat data from Idaho streams to support beneficial use determinations. Surveys of algae, macroinvertebrate, and fish communities and physical habitat are conducted each summer mainly on small streams throughout Idaho. Survey sites are selected randomly and systematically to ensure that results are representative of a broad range of conditions throughout Idaho's streams. Additionally, biological indices were developed to characterize and evaluate biological community conditions (Grafe, 2002a, 2002b; Tetra Tech, 2011). Sample collection in the main stem and tributary sites in the Big Wood River watershed was conducted by BURP in 2014 (Idaho Department of Environmental Quality, 2014).

- To meet Federal Clean Water Act requirements, the state of Idaho set water-quality standards to ensure the waters of Idaho are fishable and swimmable. IDEQ evaluated existing water-quality concerns and pollution sources in the Big Wood River watershed and published findings in the Big Wood River Watershed Management Plan (Buhidar, 2002). Total maximum daily load (TMDL) limits set for the upper Big Wood River watershed were published in both the management plan and the Agriculture Implementation Plan (Buhidar, 2002; Pentzer 2006). The TMDL documents describe segments of the Big Wood River that do not support one or more beneficial uses. Since the development of the TMDL, there has been no consistent and continuous monitoring of water-quality and biological integrity in the Big Wood River and tributaries. A 5-year review of the Big Wood TMDL is being done by IDEQ and this report will contribute to the analysis of existing data and the updating of the TMDL. Data collected by BURP will also be used in TMDL development and evaluation.

- The USGS, in cooperation with several local government agencies and organizations, has published a number of reports on the quality and quantity of water resources in the Big Wood River watershed. These reports include (1) a description of trends in surface and groundwater hydrology (Skinner and others, 2007), (2) the development of a groundwater budget (Bartolino, 2009), (3) a hydrogeologic framework for the Wood River Valley aquifer system (Bartolino and Adkins, 2012), (4) a stream seepage and groundwater levels study (Bartolino, 2014), and (5) an evaluation of the quality of groundwater and surface-water supplies (Hopkins and Bartolino, 2013). Overall, these studies concluded that most of the water supply in the Big Wood River watershed is relatively unimpaired, with low concentrations of nutrients and low levels of fecal contamination, although elevated nutrient concentrations were reported in groundwater in the eastern part of the watershed. The studies furthermore concluded that the demand for water could eventually affect the quality and quantity of groundwater and surface water resources in the watershed.

- The Idaho Department of Fish and Game (2013) published information on the status of the fishery for the Big Wood River and select tributaries. Idaho Department of Fish and Game manages the Big Wood River as a cold-water fishery and continues to assess fish population on a 3 -year rotation. The Big Wood River upstream of North Fork and parts of Trail Creek and Warm Springs Creek are managed as a put-andtake fishery. Downstream of North Fork to downstream of Bellevue, the river is managed as a wild-trout trophy fishery.

\section{Sampling and Data Analysis Methods}

U.S. Geological Survey water quality and bioassessment sampling protocols were used to collect data at selected sites in the Big Wood River watershed. Specific sampling protocol details and data analysis methods are discussed.

\section{Watershed Characterization and Site Selection}

Watershed characteristics were summarized using USGS StreamStats (U.S. Geological Survey, 2016d), a Web-based geographic information system application that delineates drainage areas and uses physical features such as slope, land use, surface geology, and discharge from national datasets to calculate statistics for a selected watershed and the National Land Cover Database 2011 (Homer and others, 2015; table 1). River kilometer, drainage area, and elevation are from U.S. Geological Survey (2016e).

Given the significant influence of stream hydrology on water quality, physical habitat, and biological communities (Carlisle and others, 2013), monitoring sites in the Big Wood River and tributaries were located near existing USGS streamgaging stations. Additionally, monitoring site locations were selected to represent as best as possible the range of existing conditions within the Big Wood River watershed, to include land and water uses, water-quality, and biological diversity. 


\section{Hydrology}

Information on daily stream stage was used to estimate continuous discharge using a stage-discharge relation described by Mueller and Wagner (2009) and Turnipseed and Sauer (2010). Discharge records for this period were computed according to methods described in Rantz and others (1982) and are available at U.S. Geological Survey (2016e). Continuous discharge for water year 2014 and the long-term median daily discharge for the period of record for each main-stem site are presented in figure 2.

The magnitude and variability of discharge are important factors affecting the occurrence and composition of fish and invertebrate communities (Sheldon and Thoms, 2006; Zuellig and others, 2007; Monk and others, 2008; Naiman and others, 2008). Changes from natural discharge could cause washout or stranding of aquatic species, timing of seasonal peaks may disrupt fish migration cues, prolonged low flow may decrease available habitat, and prolonged high flow may result in loss of riffle habitat (Poff and others, 1997). Human-caused alterations to these and other natural flow parameters can occur as increased frequency of high flows (or flood flows), fluctuations in flow between seasonal periods of high and low flows that usually occur during storm run-off, and increased variability in daily flows (Konrad and Booth, 2005). Ultimately, disruption of natural flow regimes can result in loss of physical habitat and promote conditions that favor the spread of non-native and invasive species (Poff and others, 1997; Olden and Poff, 2003). To help identify and evaluate flow-related disturbances, table 2 presents hydrologic measures that may be useful for future evaluation of instream flow alteration in the Big Wood River and tributaries. Annual and monthly (June and September) flow magnitude and variability statistics were calculated using discharge data from water years 2012 to 2015 and are summarized as annual average daily mean flow (DMF) and coefficient of variation (CV) of annual average DMF (table 2). The CV represents the variability of flow relative to the magnitude of the mean flow and is calculated as the standard deviation divided by the annual or monthly average DMF and expressed as a percentage.
A. USGS 13135500 Big Wood River near Ketchum, Idaho discharge, water year 2014

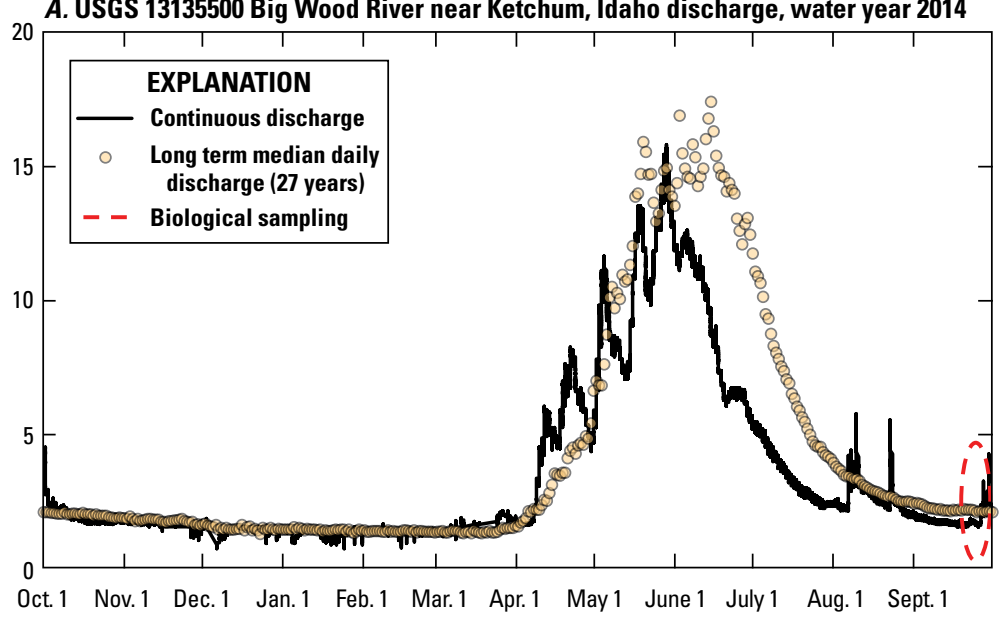

B. USGS 13135500 Big Wood River at Hailey, Idaho discharge, water year 2014

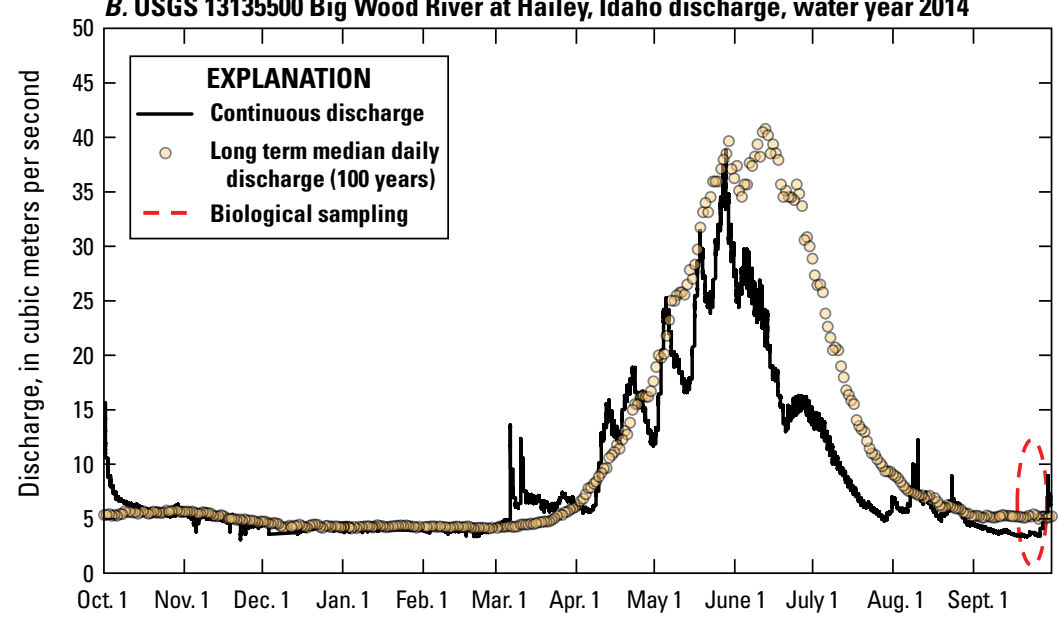

C. USGS 13135500 Big Wood River at Stanton Crossing near Bellevue, Idaho discharge, water year 2014

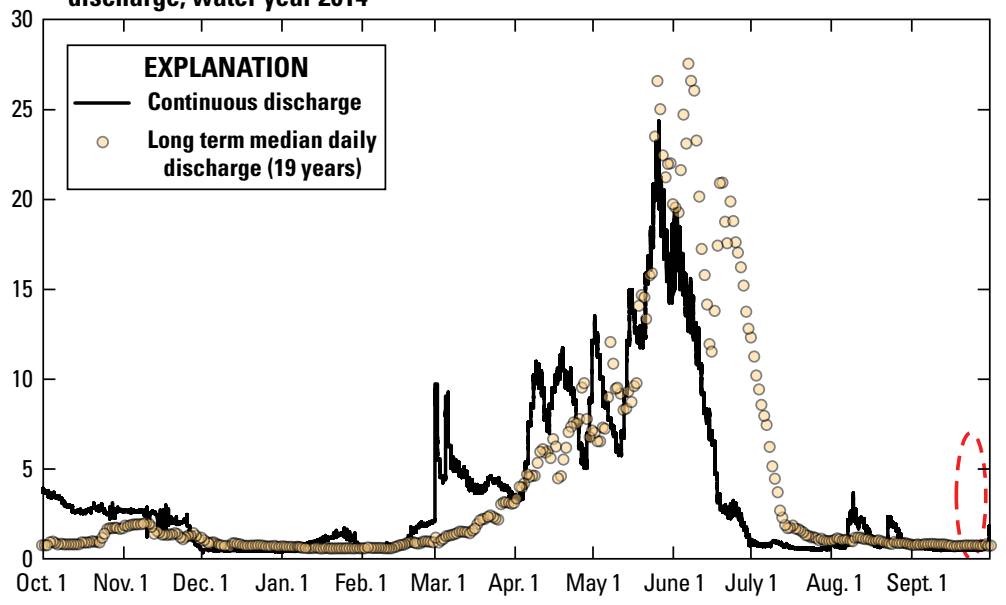

Figure 2. Discharge and long-term median daily discharge for mainstem sites on the Big Wood River, south-central Idaho, water year 2014. 


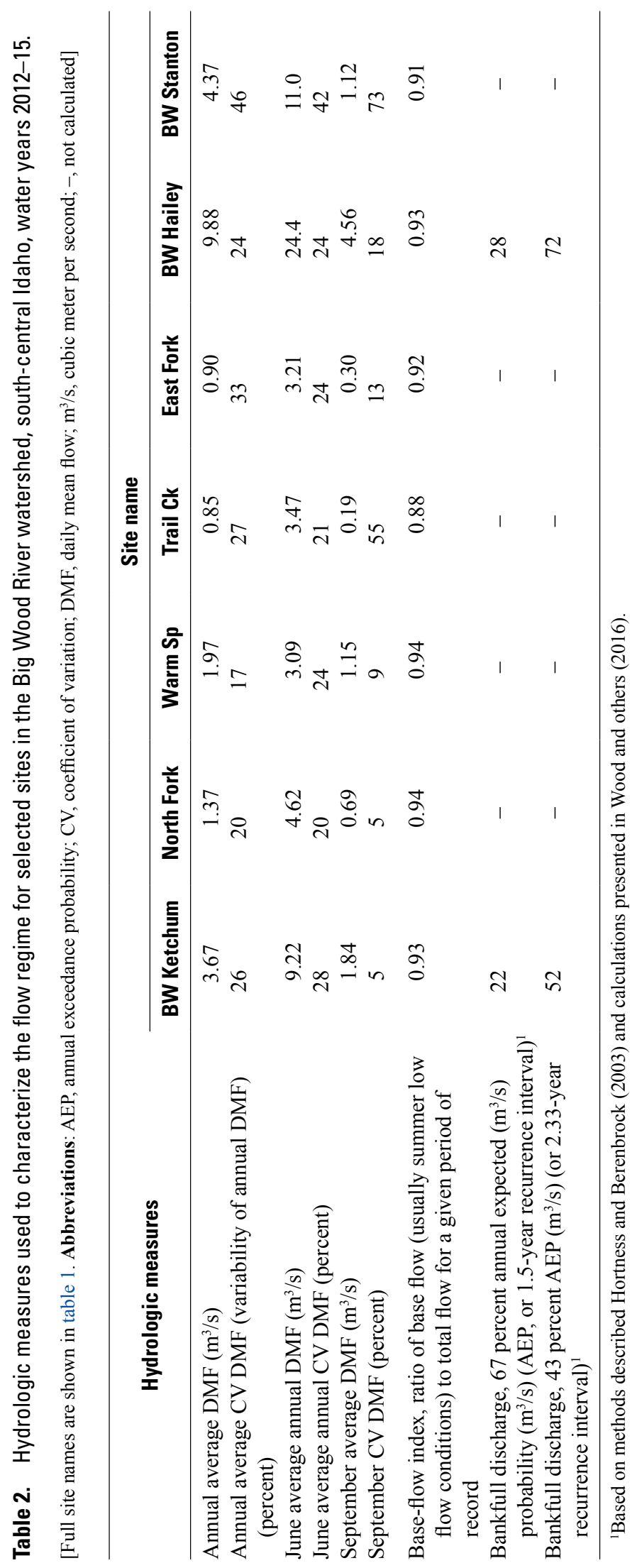


Bankfull discharge (BFD) and base-flow index (BFI) are additional hydrologic measures that can correlate strongly with occurrence and distribution patterns of stream biota (Petts and Maddock, 1997; Sheldon and Thoms, 2006; Munn and others, 2010). A BFD is considered the dominant channel-forming flow and hence is a key factor in structuring habitat conditions for fish and other stream organisms (Knighton, 1998; Doyle and others, 2005; Naiman and others, 2008). Only the USGS streamgages at BW Ketchum and BW Hailey had sufficient periods of record to calculate BFD. The BFD reported here is the 67 percent annual expected probability (AEP; or 1.5-year recurrence interval) and 43 percent AEP (or 2.33-year recurrence interval) based on methods described by Hortness and Berenbrock (2003) and calculations presented in Wood and others (2016). Base-flow index is a ratio of base flow (typically summer low-flow conditions) to total flow for a given period of record and represents the relative contribution of groundwater flow to total discharge. A BFI value of 0 indicates that all flow is derived from surface water and a value of 1 indicates that all flow comes from groundwater. Importance of groundwater flows in moderating physical-chemical properties of streams and influencing biological properties such as algal biomass accrual and invertebrate community composition has been well-documented (Constantz and others, 1994; Pepin and Hauer, 2002; Brown and others, 2007). BFI was calculated using the local minimum method of hydrograph separation or the separation of the base flow from the total flow over the discharge hydrograph (Lim and others, 2005). BFI has been used previously to evaluate trends in discharge and groundwater and surface water relations in the Big Wood River watershed (Skinner and others, 2007).

\section{Water Quality}

Surface-water samples were collected and composited from vertical transits throughout the entire stream depth using depth- and equal-width-increment (EWI) methods described in the "USGS National Field Manual" (U.S. Geological Survey, variously dated). The EWI samples were collected with an isokinetic DH-81 sampler. Water samples were consolidated in a plastic churn splitter and dispensed into separate bottles. In accordance with the "USGS National Field Manual," the churn and sampling equipment were cleaned in soapy water, rinsed in tap water, and triple rinsed with deionized water between sites. Sites were sampled in downstream order starting at the farthest upstream site. At the time of EWI water sample collection, field parameters (temperature, $\mathrm{pH}$, specific conductance, and dissolved oxygen) were determined in accordance with USGS procedures (Turnipseed and Sauer, 2010; U.S. Geological Survey, variously dated) using a six-series multiparameter water-quality sonde (Yellow Springs, Inc.). Instruments were calibrated prior to and following sampling using methods described in Wagner and others (2006).
Unfiltered water samples for total nutrient analysis were acidified with sulfuric acid and chilled at $4{ }^{\circ} \mathrm{C}$. Water samples to be analyzed for dissolved nutrients were filtered through 0.45 - $\mu \mathrm{m}$-pore-size capsule filters certified to be free from contamination, acidified with sulfuric acid, and chilled at $4{ }^{\circ} \mathrm{C}$. All the nutrient samples were shipped on ice to the USGS National Water-Quality Laboratory (NWQL) for analysis. Water concentrations of total nitrogen and phosphorus were determined using colorimetric analysis following alkaline persulfate digestion as described by Fishman (1993) and by Patton and Kryskalla (2003 and 2011) and in accordance with laboratory quality-assurance and quality-control protocols described by Pritt and Raese (1995). Unfiltered suspended sediment samples were homogenized, stored at room temperature, and shipped to the USGS Cascades Volcano Observatory Sediment Laboratory for analysis. Samples were analyzed for suspended-sediment concentration (SSC) and percentage of particles less than $0.0625 \mathrm{~mm}$ (fines) using wet sieving and filtration methods described by Guy (1969) and the American Society for Testing and Materials (2002) method D3977-97. Unfiltered water samples for fecal indicator analysis (Escherichia coli [E. coli]) were homogenized, chilled at $4{ }^{\circ} \mathrm{C}$, and delivered to the Idaho Department of Health and Welfare (IDHW), Bureau of Laboratories in Boise, Idaho within 24 hours. The most probable number (MPN) of organisms per milliliter (E. coli and total coliform) was determined for each water sample using method number 9223B as described in Standard Methods (Eaton and others, 1999).

Continuous water temperature was recorded using two Onset $^{\circledR}$ TidbiT $^{\circledR}$ thermistors (fig. 3) attached to the USGS streamgage orifice line at each site - one was the main thermistor and one was used as a backup. Temperature calibration, temperature checks, record compilation, and reporting followed USGS standard procedures (Wagner and others, 2006). Continuous temperature was recorded every 15 minutes to the nearest $0.1^{\circ} \mathrm{C}$ between May 2014 and September 2014. Monthly statistics were calculated from daily average continuous temperature measurements.

\section{Water-Quality Assurance and Quality Control}

Quality-assurance procedures used for the collection and field processing of water samples were described by Ward and Harr (1990) and U.S. Geological Survey (variously dated). The NWQL follows systematic internal quality-assurance practices as described in Friedman and Erdmann (1982) and Pritt and Raese (1995) to ensure laboratory analytical accuracy. These practices include quality-control samples such as calibration standard samples, standard reference water samples, replicate samples, deionized-water blank samples, or spiked samples at a proportion equivalent to at least 10 percent of the sample load. The NWQL participates in a blind-sample program using samples prepared by the USGS Branch of 


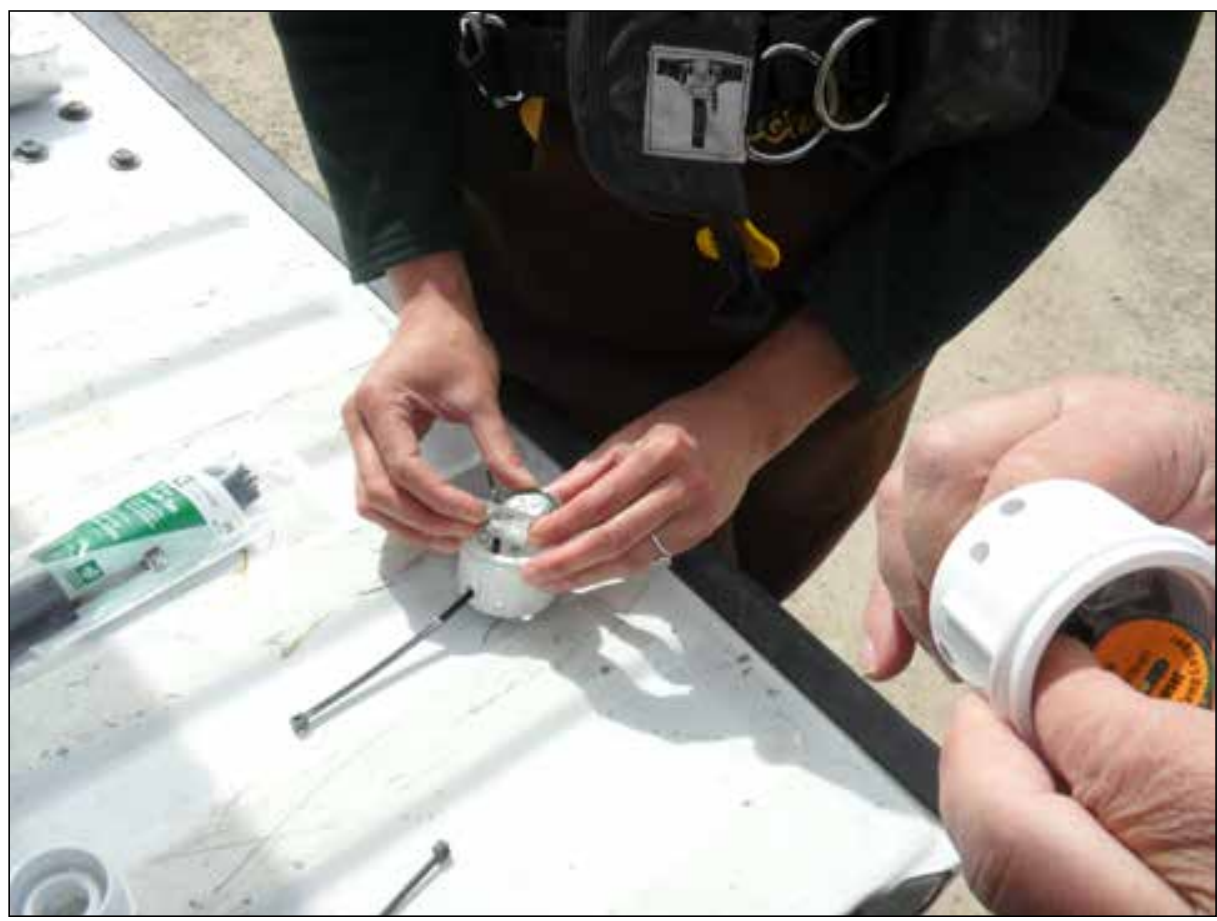

Figure 3. Assembly of Onset ${ }^{\oplus} \mathrm{TidbiT}^{\oplus}$ thermistors to be attached to streamgage orifice line. Photograph by Dorene E. MacCoy, U.S. Geological Survey.

Quality Systems (U.S. Geological Survey, 2016f) that are routinely inserted into the sample line. The laboratory also participates in external evaluation studies and audits with the National Environmental Laboratory Accreditation Program to assess analytical performance.

Suspended sediment processing and analysis by Cascades Volcano Observatory adheres to quality-control and quality-assurance procedures described by Knott and others (1993). These include frequent instrument calibration, standard conductivity and reagent checks, as well as split, spiked, blank, and reference sample analysis.

The IDHW follows standard operating procedures (SOP) for simultaneous detection or enumeration of total coliform and E. coli using defined substrate $\left(\right.$ Colilert ${ }^{\circledR}$ and Colilert-1 $8^{\circledR}$ ). Biological controls and sterility checks are used to calibrate and check instrumentation. Colilert reagent is checked with a known concentration of a control organism before use and then quarterly, until the reagent is completely consumed or reaches expiration, with a target concentration of approximately 100 organisms $/ 100 \mathrm{~mL}$. Additionally, each batch of testing vessels is checked for sterility, volumetric accuracy, and auto-fluorescence before use. Reagent and testing materials are rejected if quality control parameters are not met (Standard operating procedure MIC-SM9223B, version 6.0, Ernest Bader, written commun., January 19, 2016).

The quality of analytical results reported for water samples was evaluated using quality-control samples that were submitted concurrently with environmental samples.
Water-quality sample results were reviewed after receipt of the laboratory analysis. Data validation included use of a relative percent difference (RPD) to evaluate the relation between the dissolved nutrient concentrations and whole-water concentrations. RPDs were calculated using the absolute value of the difference between the result pair, divided by the mean of the result pair, multiplied by 100 . Expressing precision relative to a mean concentration standardizes comparison of precision among individual constituents. Laboratory analyses are rerun and (or) verified when the dissolved fraction exceeded the whole-water fraction with an RPD greater than 10 percent. Nutrient, suspended sediment, and bacteria results were reviewed for anomalies in relation to historical results at the same location if data were available.

Replicate data were used to assess the precision (reproducibility) of the analytical results. Replicate samples are two or more samples considered to be essentially identical in composition. Replicate samples can be obtained in the field (field replicate) by either repeating the collection process to obtain two or more independent composite samples (concurrent field replicate) or by splitting a single composite sample into two or more subsamples (split field replicate). The individual replicate samples are then analyzed separately. Likewise, a single sample can be analyzed two or more times in the laboratory to obtain a measure of analytical precision (laboratory replicate). All replicate samples collected as part of this study were split field replicates and were used to indicate the reproducibility of environmental data that are affected by variability potentially introduced by field and 
laboratory processes. The precision of the analytical results was determined using the RPD between the environmental sample and the split replicate. An RPD of less than 25 percent was considered acceptable because of the low concentrations of constituents (near analytical detection), especially for nutrients. The RPD was evaluated for split replicate total coliform and E. coli bacteria samples. However, because those results are reported as an MPN, no specific RPD acceptability value was targeted.

Blank samples identify the presence and magnitude of potential contamination that could bias analytical results. Field blanks are aliquots of deionized water that are certified as contaminant-free and are processed through the sampling equipment used to collect stream samples. All blanks were collected as field blanks. Field blanks are subjected to the same processing (sample splitting, filtration, preservation, transportation, and laboratory handling) as environmental samples. Blank samples were analyzed for the same constituents as the environmental samples.

Replicate samples for suspended sediment and E. coli were collected at Trail Ck. Replicate samples for nutrient analysis were collected at both Trail Ck and BW Stanton. All replicate samples met data-quality objectives and did not exceed the 25 percent RPD criteria. Additionally, equipment blanks collected at BW Stanton were analyzed for nutrient contamination, with no detectable results.

\section{Periphyton}

Samples of periphyton (biofilm attached to rock surfaces) were collected from as many as 25 cobbles in or near each riffle targeted for macroinvertebrate collections using methods described in Moulton and others (2002). Periphyton samples were removed from cobbles by using the bottom portion of a 30-mL syringe fitted with a neoprene O-ring to form a watertight seal against a rock surface. Filtered stream water $(5 \mathrm{~mL})$ was added to the syringe barrel, and attached materials were dislodged from the rock surface with a stiff-bristle brush and collected with a hand pipette. Individual samples were composited and total sample volume determined. A 5-10 mL aliquot of the composited sample was filtered through a $0.7-\mu \mathrm{m}$ glass-fiber filter. Filters were then wrapped in aluminum foil and frozen until analyzed for concentrations of chlorophyll- $a$ and biomass (ash-free dry weight) by the Bureau of Reclamation, Pacific Northwest Regional Laboratory in Boise, Idaho, using standard analytical methods (standard method 10200H; Eaton and others, 1999).

\section{Physical Habitat}

Measures of physical habitat include discharge, channel morphology, substrate composition, habitat cover, and riparian canopy density and are based on methods described in Fitzpatrick and others (1998). Eleven equidistant transects perpendicular to the direction of flow were established within the longitudinal boundaries (150-400 m) of each sampling reach. Wetted channel width was measured at each transect location and averaged for the entire length of the reach. Wetted depth and flow velocity were measured at five locations along each transect and an average value reported for each study reach. Streambed substrate composition was quantified at each transect location using a modification of the Wolman pebble count technique (Wolman, 1954). At each transect, the presence of habitat cover type (over-hanging vegetation, undercut banks, woody debris, boulders, macrophytes, artificial structures) that could provide refuge for fish or other organisms was recorded at channel margins near the edge of water and at three other locations in the main channel. The proportion of cover types occurring within a stream reach was calculated as percent cover. Riparian vegetation density (percent) was measured near stream channel margins at each transect location using a hemispherical densitometer (Platts and others, 1987).

The amount of variability among habitat measures such as channel wetted width, depth of water, flow velocity, and substrate particle size can be used to evaluate overall habitat conditions occurring along the length of a study reach. Stream channels where dimensions of physical properties are relatively uniform throughout the reach (low variability), such as might occur in highly channelized streams, typically are less biologically diverse than streams where conditions are more heterogeneous throughout (Kaufmann and others, 1999). Variability among physical habitat parameters was determined as the $\mathrm{CV}$ of the total individual transect-based determinations collected in each reach (55 determinations per reach). The product of reach length and reach-averaged wetted width and depth is the wetted volume (WV) for a given length of stream channel, and this measure can be used to estimate the total amount of available habitat space for a defined stream reach (Gordon and others, 1993). This metric provides a general indication of the potential habitat capacity of a streamessentially the habitable space of a stream region available to support populations of fish and other organisms. Streams with a relatively large $\mathrm{WV}$ are more likely to have greater numbers of fish than smaller streams with more limited habitat areas. Because WV will increase with increasing reach length, the WV was calculated based on a standard reach length of $150 \mathrm{~m}$.

\section{Biological Communities}

Benthic macroinvertebrate and fish communities were sampled using protocols developed by the USGS National Water-Quality Assessment (NAWQA) Program (Moulton and others, 2002). The USGS NAWQA sampling protocols have been thoroughly tested in streams and rivers throughout the conterminous United States, Alaska, and Hawaii, and are designed using nationally consistent sampling and analytical methods. 


\section{Macroinvertebrates}

Quantitative macroinvertebrate samples were collected from rock substrates using a modified D-frame net fitted with a $500 \mu \mathrm{m}$-mesh net and a detachable collection receptacle. Macroinvertebrates were collected from a $0.25-\mathrm{m}^{2}$ area immediately upstream of the sampler by systematically removing attached organisms from rocks and other substrate surfaces. Individual samples were collected from five locations distributed in riffle regions throughout each stream reach and composited into a single sample. Each sample was cleaned of extraneous inorganic and organic materials by elutriation, preserved in ethanol, and shipped to EcoAnalysts in Moscow, Idaho, for taxonomic identification and enumeration. The EcoStandard West procedure was used to identify macroinvertebrates to the lowest taxonomic level possible (usually genus or species) and all biological community data were uploaded to the USGS BioData website (U.S. Geological Survey, 2016b).

Macroinvertebrate assemblage data was summarized using USGS Invertebrate Data Analysis System (IDAS) software (Cuffney and Brightbill, 2011). IDAS provides methods of resolving ambiguous taxa and calculating macroinvertebrate metrics and specific indices. Metrics selected for analysis were those that have been effective in diagnosing macroinvertebrate community health in Idaho streams. Among these were mayflies [ephemeroptera]; stoneflies [plecoptera]; and caddisflies [trichoptera], EPT taxa richness and total taxa richness (number of unique taxa in a sample). Generally, least disturbed streams in Idaho have higher EPT and taxa richness and can be used as indicators of healthy cold-water streams (Maret and others, 2001).

Disturbance effects on benthic macroinvertebrate communities often manifest as alterations in community composition (Resh and others, 1988), although compositional characteristics such as taxa richness and density can generate opposite patterns of community response to disturbance (McCabe and Gotelli, 2000) depending on the intensity, areal extent, and frequency of the disturbance (Resh and others 1988; Townsend and others, 1997). Community responses to conditions of water quality and physical habitat were examined by comparing taxa richness and density ratios (RD) among sampling locations. Taxa richness and density values for each site were log transformed prior to calculation of RD.

Environmental framework documents were developed in 2002 by IDEQ in order to evaluate the biological integrity of Idaho streams and rivers (Grafe, 2002a, 2002b). This document stated that multiple indices of biological communities (algae, macroinvertebrates, fish, and habitat) would help the State of Idaho identify waters that may or may not be in full support of their designated beneficial uses of fishable and swimmable. In 2011, IDEQ began the process to update the 2002 water-body assessment framework using BURP data collected from more than 3,000 sites in Idaho.
For this evaluation, Idaho streams were categorized into three groups based on level 4 ecoregions listed in figure 1 and associated macroinvertebrate community data (Tetra Tech, 2011). The stream-based ecoregions (IDEQ ecoregions) were designated Mountain, Foothills, and, collectively, Plains, Plateaus, and Broad Valleys (PPBV). The Big Wood River sites are in both the Mountain and PPBV IDEQ ecoregions. A stream macroinvertebrate index (SMI2) was developed for each IDEQ ecoregion using species trait characteristics that are meant to be the most responsive to regional environmental conditions. The PPBV SMI2 metrics include Simpson's $\mathrm{D}$ (species diversity index), percent non-insects, percent filter feeders, percent tolerant species, percent clingers, and number of semi-voltine taxa (taxa that take more than 1 year to complete their life-cycle, considered to be long-lived). The Mountain SMI2 include the number of clinger taxa, percent ephemeroptera and plecoptera, number of EPT taxa, percent filterers, modified Hilsenhoff Biotic Index (diversity index based on sensitivity to organic pollution), number of semi-voltine taxa, and total number of taxa. As of 2016, the State of Idaho has not developed scoring criteria for SMI2, and the values published in this report are for future reference. The SMI2 values generally range from 0 (most disturbed conditions) to 100 (least disturbed conditions). The reference values calculated for PPBV SMI 2 are between 50 and 94, and for the Mountains SMI2 between 33 and 94 (Jason Papanni, Idaho Department of Environmental Quality, written commun., September 2015). See Tetra Tech (2011) for a more detailed description of IDEQ ecoregion groupings and SMI2 development.

Tolerance metrics and biological indices help identify macroinvertebrate communities that may be susceptible to individual or combinations of physical and chemical stressors. Relations between macroinvertebrate assemblages and compositional characteristics of streambed substrates can be examined using the Fine Bed Sediment Index (FBSI) developed by Relyea and others (2012). The FSBI is based on occurrence patterns of macroinvertebrate taxa in northwestern streams having markedly different substrate compositional characteristics. High FSBI values are indicative of streams with a relatively low percentage of substrate fines and high abundance of fine sediment sensitive species, whereas low FSBI values indicate streams with a high percentage of species not sensitive to substrates dominated by fine-grained particles. In the Northern Mountains level 3 ecoregion, the typical FSBI values range between 0 and 350, with the lowest values $(<50)$ containing as much as 100 percent fine sediment (defined as particles $<2 \mathrm{~mm}$ in Relyea, 2012).

Macroinvertebrate indicator values (tolerances) for nutrients, water temperature, and suspended sediment were based on ecological trait information provided by U.S. Environmental Protection Agency (2012). Tolerance values range from 0 (lowest tolerance) to 10 (highest tolerance). 
Tolerance values were abundance weighted to account for differences among sites in macroinvertebrate densities and to normalize tolerance values for among-site comparisons. Tolerance categories were arbitrarily defined and based on ranges of tolerance values where low was less than or equal to 3 , moderate was $3-6$, and high was greater than 6-10.

\section{Fish}

Fish communities were sampled during base-flow conditions in September 2014 using pulsed direct-current backpack and barge electrofishing as described in Moulton and others (2002). For most sites, electrofishing began at the downstream boundary of the sampling reach and a single pass was done in an upstream direction. For the larger BW Hailey site barge, electrofishing was used and sampling conducted in a downstream direction. All habitats were systematically surveyed along the entire length of the sampling reach. All captured fish were identified to species, counted, measured for length and weight, and examined for external anomalies. Voucher specimens, primarily Wood River sculpin, were verified at the Orma J. Smith Academy of Sciences museum at the College of Idaho in Caldwell, Idaho. All fish species and sampling information was entered into BioData at U.S. Geological Survey (2016b).

The environmental framework documents developed by IDEQ to evaluate the biological integrity of Idaho's streams and rivers (Grafe, 2002a, 2002b) included the original River Fish Index (2002 RFI) and the Stream Fish Index (2002 SFI). The 2002 RFI and SFI were revised and IDEQ developed the new 2011 river and stream fish indices (RFI2 and SFI2; Tetra Tech, 2011). Similar to the SMI2, the SFI2 used metrics specific to IDEQ ecoregions (Tetra Tech, 2011). The Big Wood River is mainly in the PPBV IDEQ ecoregion with the upstream-most sites in the Mountains IDEQ ecoregion. The PPBV SFI2 includes the number of native fish taxa, and the percentages non-native fish taxa, minnows, lithophilic spawners (fish that spawn in gravel), invertivores (fish feeding on invertebrates), and piscivores (fish feeding on other fish). The Mountains SFI2 includes number of native fish taxa, individuals per native taxon, percent invertivores, percent lithophilic spawners, and percent native intolerant individuals (Tetra Tech, 2011). The State of Idaho has not finalized scoring criteria for the SFI2, and the values published in this report are for general reference. SFI2 values reported here range from 0 (most disturbed conditions) to 100 (least disturbed conditions). The reference values calculated for PPBV SFI2 are between 61 and 99, and for the Mountains SFI2 between 30 and 100 (Jason Papanni, Idaho Department of Environmental Quality, written commun., October 2015).

\section{Aquatic Biological Communities and Habitats}

Hydrologic, water quality, and physical habitat data associated with the 2014 biological community samples provide information about the environment available for aquatic organisms in the Big Wood River watershed. It is important to note that this was a one-time sampling event and that aquatic organisms integrate these and possibly more parameters over time. Findings from this initial assessment are given below.

\section{Hydrology}

Seasonal flow patterns for the Big Wood River and tributaries are typical of a snow-melt driven system with peak flows usually occurring during spring runoff (fig. 2). Peak discharges during WY 2014 occurred in late May and early June for the main-stem sites, with peak discharge of $15 \mathrm{~m}^{3} / \mathrm{s}$ at BW Ketchum, $39 \mathrm{~m}^{3} / \mathrm{s}$ at BW Hailey, and $24 \mathrm{~m}^{3} / \mathrm{s}$ at BW Stanton. Lower peak flows downstream of the BW Hailey site at the BW Stanton site may have resulted from water diversion upstream of BW Stanton during the beginning of the irrigation season. Peak flows for the Big Wood River in 2014 occurred somewhat earlier than historical occurrences based on the period of record for these sites (fig. 2) and reflect a more recent pattern of earlier snowmelt runoff occurring in rivers throughout the Western United States (Stewart and others, 2004; McCabe and Clark, 2005; Clow, 2008).

Average DMF for water years 2012-15 for sites on the Big Wood River increased in magnitude downstream of BW Ketchum $\left(3.67 \mathrm{~m}^{3} / \mathrm{s}\right)$ to BW Hailey $\left(9.88 \mathrm{~m}^{3} / \mathrm{s}\right)$, but decreased to $4.37 \mathrm{~m}^{3} / \mathrm{s}$ at BW Stanton (table 2). Flow variability (expressed as the coefficient of variation of annual DMF) was similar for BW Ketchum and BW Hailey (26 and 24 percent, respectively), but increased to 46 percent at BW Stanton (table 2). Generally, with the exception of BW Stanton, differences among tributary and main-stem sites in annual variability of DMF were not remarkable (ranging between 17 and 33 percent), and probably reflect naturally occurring seasonal changes in discharge (table 2). Discharges are typically greatest during late spring to early summer, and on the Big Wood River, average DMF for June was $9.22 \mathrm{~m}^{3} / \mathrm{s}$ at BW Ketchum and $24.4 \mathrm{~m}^{3} / \mathrm{s}$ downstream at BW Hailey (table 2). In unaltered systems, discharge typically increases downstream as corresponding drainage area increases; however, June DMF downstream of BW Hailey decreased by one-half at BW Stanton to $11.0 \mathrm{~m}^{3} / \mathrm{s}$ (fig. 2, table 2). 
Additionally, flow variability for June was highest among sites at BW Stanton (DMF CV of 42 percent, table 2). Reduced and more variable June flows occurring at BW Stanton likely result from flow diversions downstream of BW Hailey to support increased agricultural demands during early summer and possible leakage to groundwater (Bartolino, 2014).

On average, September DMF for main-stem sites on the Big Wood River was about 16 percent of the June DMF, with the highest flows $\left(4.56 \mathrm{~m}^{3} / \mathrm{s}\right)$ recorded at BW Hailey. Flows decreased downstream at the BW Stanton site to $1.12 \mathrm{~m}^{3} / \mathrm{s}$ during this time. Tributary flows in September also were at their seasonal low and ranged between $0.19 \mathrm{~m}^{3} / \mathrm{s}$ at Trail $\mathrm{Ck}$ to $1.15 \mathrm{~m}^{3} / \mathrm{s}$ at Warm Sp. The CV in DMF was lower at most sites in the month of September compared to June and is indicative of the time of year when daily discharge is greatly reduced and antecedent flow conditions are relatively stable (table 2). However, flow conditions in the lower part of the watershed can be highly variable depending on water use patterns during the end of the irrigation season, as evident at BW Stanton with a CV DMF of 73 percent for September. High flow variability (CV DMF of 55 percent) for the Trail Ck site (table 2) may have been partly due to summer storms, which are frequent in the upper part of the watershed.
The BFD estimates for BW Ketchum and BW Hailey reported in table 2 represent conditions when the stream channels are at capacity with the water at the top of the channel bank at the level of the floodplain. For most streams this typically occurs in the spring as a result of rain- or snowmelt-driven runoff events, and has a recurrence interval between 1 and 2 years (Leopold, 1994). Differences in BFD between BW Ketchum and BW Hailey largely result from differences in drainage areas (table 1), with BFD increasing with increasing drainage area. Estimates of BFD reported in table 2 are included as a reference for comparing magnitudes of peak flows for streams in the watershed and the potential of these flows as channel- and habitat-forming events.

Annual BFI values for sites in the Big Wood River watershed indicated that discharge is dominated by groundwater throughout most of the year (BFI near 1, table 2). However, in August 2014 significant contributions of surfacewater inputs to total daily discharge (where surface water is greater than 50 percent of total flow) were apparent at the Trail Ck tributary and at BW Stanton (fig. 4). For these sites, 36 and 13 percent, respectively, of the total daily flows during August were derived primarily from surface water inputs (fig. 4), possibly from late summer storms in the Trail Ck drainage or return flows for BW Stanton.

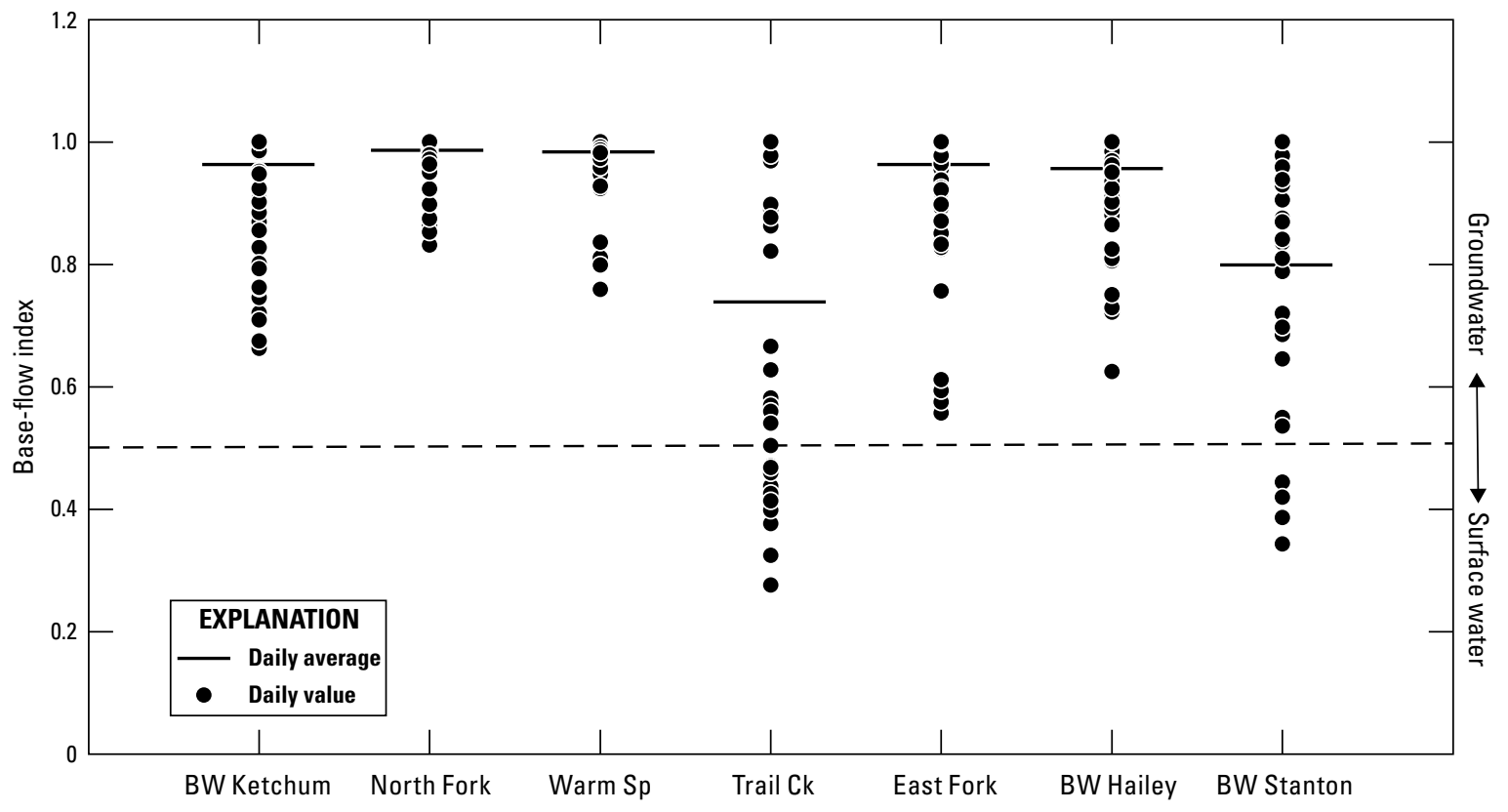

Figure 4. Base-flow index values for selected sampling sites in the Big Wood River and tributaries, south-central Idaho, August 2014. Full site names are shown in table 1. 


\section{Water Quality}

Samples collected in September 2014 consisted of a single sampling event and was intended to characterize water-quality conditions at the time of sampling and not to provide information on long-term water-quality conditions or potential effects to aquatic communities. Nevertheless, these initial results provide information on water-quality for streams in the Big Wood River watershed during base flow when conditions are often most stressful to stream organisms.

Water-quality and recommended TMDL values for the upper Big Wood River watershed are presented in table 3. Suspended-sediment concentrations were low and ranged from $1 \mathrm{mg} / \mathrm{L}$ at the North Fork and East Fork sites to $13 \mathrm{mg} / \mathrm{L}$ at Warm Sp, well within the recommended TMDL target concentration for suspended sediment of less than $25 \mathrm{mg} / \mathrm{L}$ (Buhidar, 2002). Similarly, nutrient concentrations among the tributary and main-stem sites were low. Nitrate plus nitrite concentrations ranged from less than 0.04 to $0.073 \mathrm{mg} / \mathrm{L}$ and were within the recommended TMDL of less than $0.30 \mathrm{mg} / \mathrm{L}$. Total phosphorus concentrations were within the TMDL target of less than $0.050 \mathrm{mg} / \mathrm{L}$ for all sites with the exception of Warm Sp with a total phosphorus concentration of $0.055 \mathrm{mg} / \mathrm{L}$. This value is within the 20 percent analytical variability for total phosphorus and may not be considered as exceeding TMDL. Periphyton accrual was limited at all main-stem and tributary sites as evident by low concentrations of chlorophyll- $a$ and biomass (ash free dry weight) (table 3). Chlorophyll- $a$ concentrations ranged from $2 \mathrm{mg} / \mathrm{m}^{2}$ at BW Ketchum to $86 \mathrm{mg} / \mathrm{m}^{2}$ at Trail $\mathrm{Ck}$, and biomass concentrations were near detection limits at most locations. Although physical factors such as flow velocity, riparian shading, and substrate composition can affect algal accrual rates (Biggs, 2000; Munn and others, 2010), nutrients assume a greater influence on algal growth during periods of relatively low and stable streamflow (Biggs and Close, 1989; Lohman and others, 1992), as was present during the September sampling. Results of the periphyton sampling suggest that nutrient and organic enrichment was not a significant factor affecting water quality at the sampling locations. E. coli concentrations were also low in stream water at all, sites with the highest levels of $43 \mathrm{MPN} / 100 \mathrm{~mL}$ at Trail Ck. The E. coli recommended TMDL concentration is based on a geometric mean value of five samples collected within a month (primary and secondary contact less than 126 most probable number per 100 milliliters [MPN/100 mL]) and on an instantaneous value (primary contact, less than $406 \mathrm{MPN} / 100 \mathrm{~mL}$ and secondary contact, less than $576 \mathrm{MPN} / 100 \mathrm{~mL}$ ). Concentrations of $E$. coli in the Big Wood River and tributary sites were well within TMDL target levels.
The State of Idaho has designated the Big Wood River subbasin as cold water (Buhidar, 2002), and as such it is required to meet cold-water aquatic life criteria. Streams designated as cold water are those having a daily maximum temperature less than $22{ }^{\circ} \mathrm{C}$ or a daily average temperature of less than $19{ }^{\circ} \mathrm{C}$ (Idaho Department of Environmental Quality, 2013; 2015). The state daily maximum temperature criterion of $22{ }^{\circ} \mathrm{C}$ is applicable during the index period between May 4 and September 24. This value was exceeded only at Warm Sp and BW Stanton during summer 2014 (table 4, fig. 5). The salmonid spawning criteria of $13{ }^{\circ} \mathrm{C}$ applies during the critical spawning and rearing periods (critical periods) for species that occur in a watershed (Buhidar, 2002; Miller and others, 2014). Exceedance of temperature criteria will differ based on salmonid reproductive behavior. For autumn spawners in Idaho, such as brown trout (Salmo trutta) in the Big Wood River, the critical period is during spawning and early stages of incubation and emergence when stream temperatures begin to cool, approximately October 1 through June 30 (Miller and others, 2014). The opposite is true for spring spawners, such as rainbow trout, where the later stages of incubation through emergence are a more critical period, approximately March 15-July 15. The temperature critical period was exceeded for rainbow trout in early July 2014 at BW Ketchum and BW Hailey, and was exceeded May through July during most of the rainbow and brown trout critical period at BW Stanton (fig. 5).

Various hydrological, topographical, and meteorological factors are responsible for temperature patterns in streams and rivers (Allan, 1995). The direction of discharge (whether the stream channel is predominantly parallel or perpendicular to the angle of the sun during daylight hours), the amount of streamside vegetation (which affects the amount of shading), and the channel shape (for example, deep and narrow versus wide and shallow), all affect stream temperature by influencing the amount of sunlight reaching the water surface. Precipitation in the form of rain or snow also can have a warming or cooling influence on stream temperature. One of the most important factors affecting stream temperature is the influence of groundwater, which tends to have a moderating effect on temperature extremes (Findlay, 1995). For streams in the Big Wood River watershed, groundwater contributes greater than 85 percent of the total flow during summer when streams are at or near base-flow (table 2). Increased groundwater withdrawal, combined with variable surface water reallocation, can have a significant effect on stream temperatures in the watershed by increasing average daily water temperatures and the frequency of high temperature periods. 


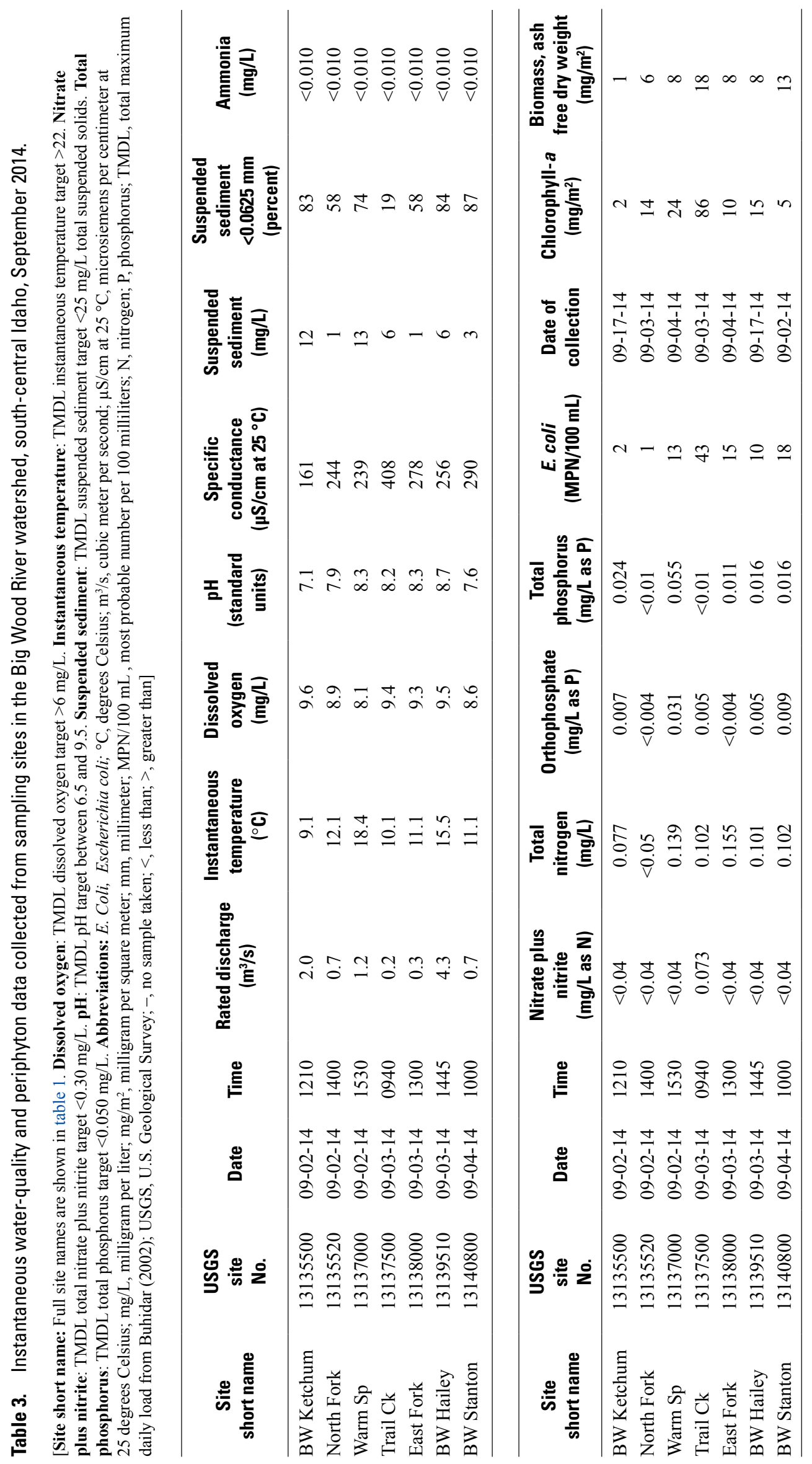



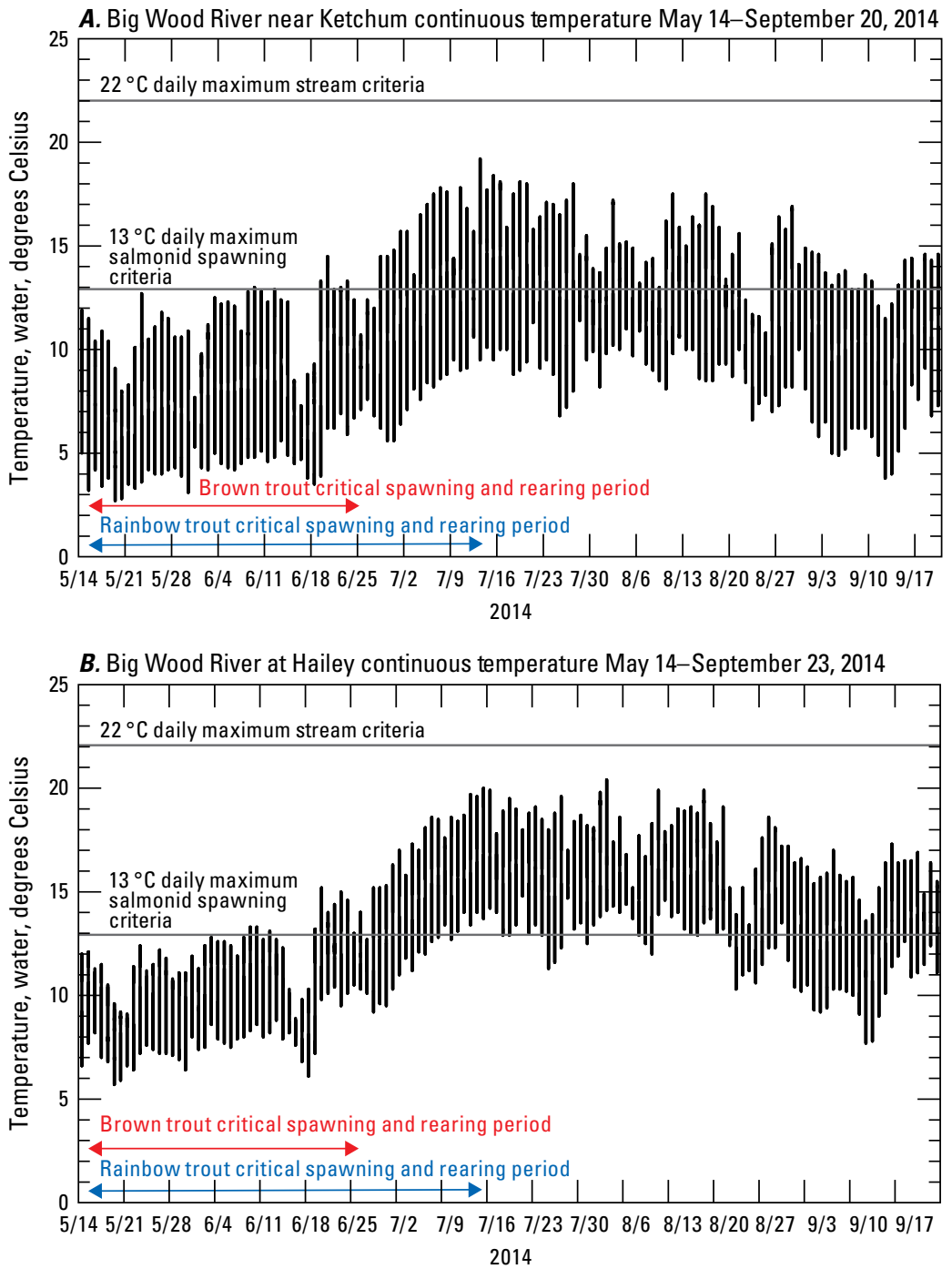

C. Big Wood River at Stanton Crossing continuous temperature May 14-September 23, 2014

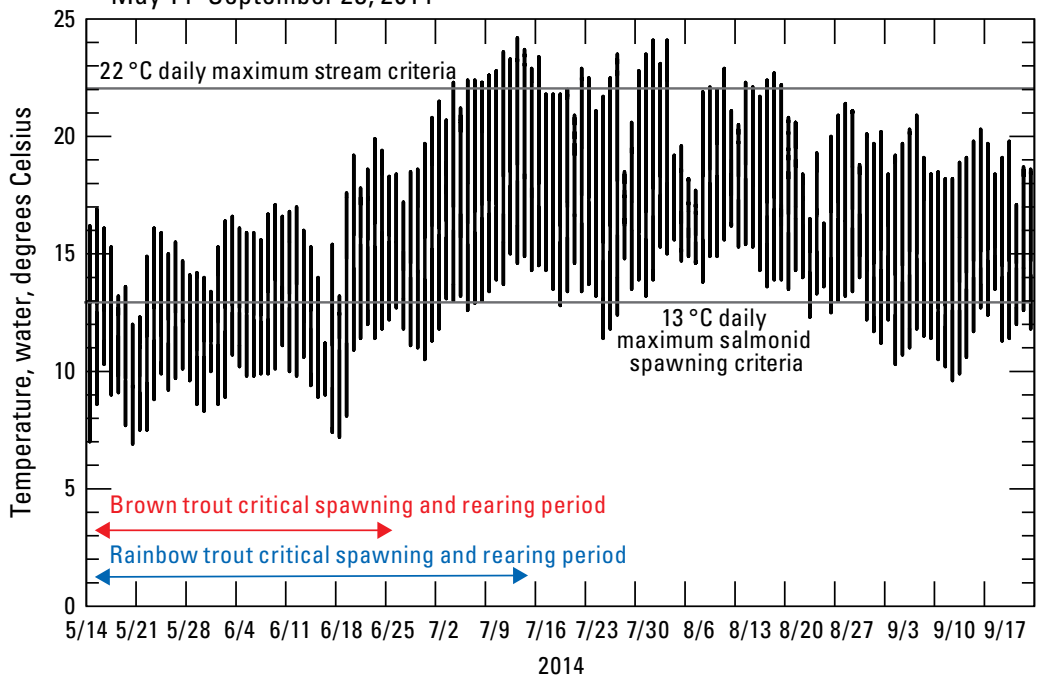

Figure 5. Continuous temperature for main-stem sites on the Big Wood River, south-central Idaho, May-September 2014. Full site names are shown in table 1. 
Table 4. Daily mean temperatures for selected sites in the Big Wood River watershed, south-central Idaho, June-September 2014.

[Site short name: Full site names are shown in table 1. Daily mean temperature and range (minimum to maximum), in degrees Celsius]

\begin{tabular}{|c|c|c|c|c|c|c|c|c|c|}
\hline \multirow{2}{*}{$\begin{array}{c}\text { Site } \\
\text { short name }\end{array}$} & \multicolumn{2}{|c|}{ June } & \multicolumn{2}{|c|}{ July } & \multicolumn{2}{|c|}{ August } & \multicolumn{2}{|c|}{ September } & \multirow{2}{*}{$\begin{array}{c}\text { Mean summer } \\
\text { temperatures } \\
\text { June-Septembe }\end{array}$} \\
\hline & Mean & Range & Mean & Range & Mean & Range & Mean & Range & \\
\hline BW Ketchum & 8.5 & $3.5-14.7$ & 12.8 & $6.4-19.2$ & 11.9 & $6.6-17.5$ & 9.8 & $3.8-14.7$ & 10.7 \\
\hline North Fork & 6.9 & $3.3-12.5$ & 10.7 & $5.5-16.6$ & 10.8 & $6.9-17.0$ & 9.0 & $3.9-14.5$ & 9.4 \\
\hline Warm Sp & 12.6 & $6.8-19.3$ & 17.9 & $11.5-23.5$ & 16.8 & $11.4-23.0$ & 14.8 & $9.0-19.7$ & 15.5 \\
\hline Trail Ck & 8.7 & $4.9-12.3$ & 13.6 & $9.4-17.2$ & 13.4 & $9.2-17.6$ & 11.8 & $6.7-15.7$ & 11.9 \\
\hline East Fork & 9.1 & $4.3-14.5$ & 14.4 & $7.8-19.9$ & 14.1 & $9.2-19.8$ & 11.2 & $5.4-15.3$ & 12.2 \\
\hline BW Hailey & 10.8 & $6.1-15.3$ & 15.4 & $10.3-20.0$ & 15.1 & $10.3-20.4$ & 12.9 & $7.7-17.3$ & 13.6 \\
\hline BW Stanton & 13.2 & $7.2-19.9$ & 17.3 & $11.3-24.2$ & 17.1 & $12.2-24.1$ & 14.6 & $9.6-20.9$ & 15.6 \\
\hline
\end{tabular}

\section{Physical Habitat}

Sampling reaches for the Big Wood River main-stem sites were between 300 and $400 \mathrm{~m}$ long and for the tributary sites between 150 and $200 \mathrm{~m}$ (table 5). Wetted channel widths were relatively uniform among sampling reaches $(\mathrm{CV}<30$ percent $)$, whereas stream depth varied within and among streams, with $\mathrm{CV}$ of mean channel depth ranging from 19 percent at BW Ketchum to 60 percent at Trail Ck (table 5). Among Big Wood River sites, wetted volume (table 5) in September 2014 was greatest at BW Hailey $\left(1,395 \mathrm{~m}^{3}\right)$ compared to BW Ketchum $\left(627 \mathrm{~m}^{3}\right)$ and BW Stanton $\left(411 \mathrm{~m}^{3}\right)$. The relatively lower wetted volume and high width to depth ratio of 69 (indicating a wider and shallower stream) at BW Stanton suggests that availability of fish habitat may be the most limited of the main-stem sites. Mean water column velocity during the September 2014 sampling for the Trail Ck and East Fork tributaries was less than $0.5 \mathrm{~m} / \mathrm{s}$, and sampling reach wetted volumes were correspondingly low (156 and $140 \mathrm{~m}^{3}$, respectively). Wetted volumes for sampling reaches on North Fork and Warm Sp sites (357 and $390 \mathrm{~m}^{3}$, respectively) were larger and similar in size to BW Stanton.

Streambed substrate composition was similar among all sites and dominated by small to large cobble-size particles (table 5). There was little evidence of extensive sedimentation at most of the sampling sites, and overall fine-grained particles ( $<2 \mathrm{~mm}$ diameter) were less than 10 percent of the substrate composition, except for the two tributary sites at Warm Sp (24 percent) and Trail Ck (14 percent).
Riparian vegetation is especially important to the health of stream ecosystems because it stabilizes stream banks and reduces soil erosion, provides food and habitat structure for stream organisms in the form of leaf litter and woody debris, and mitigates seasonal temperature extremes through shading of the stream channel (Carlisle and others, 2013). The average amount of riparian vegetative cover was greater than 30 percent for all study sites in the Big Wood River watershed with the highest densities ( $>60$ percent) occurring at the North Fork, Warm Sp, and East Fork, and BW Stanton sites.

The complexity and stability of fish and other communities in a stream environment are in large part a function of the numbers and types of habitat cover occurring within the stream channel (Cummins, 1979; Maddock, 1999; Rosenfeld, 2003). The amount of habitat cover is critical to the well-being of fish and other stream organisms and has been shown to be directly related to trout survival in cold-water streams (Penaluna and others, 2015). Abundance of habitat cover (percent over-hanging vegetation, undercut banks, woody debris, boulders, macrophytes, or artificial structures within a reach) for the tributary sites ranged from 33 percent at Trail Ck to 87 percent at the North Fork and East Fork sites (table 5). Habitat cover was abundant at BW Ketchum and BW Hailey (100 and 71 percent, respectively), but limited at BW Stanton (7 percent). 


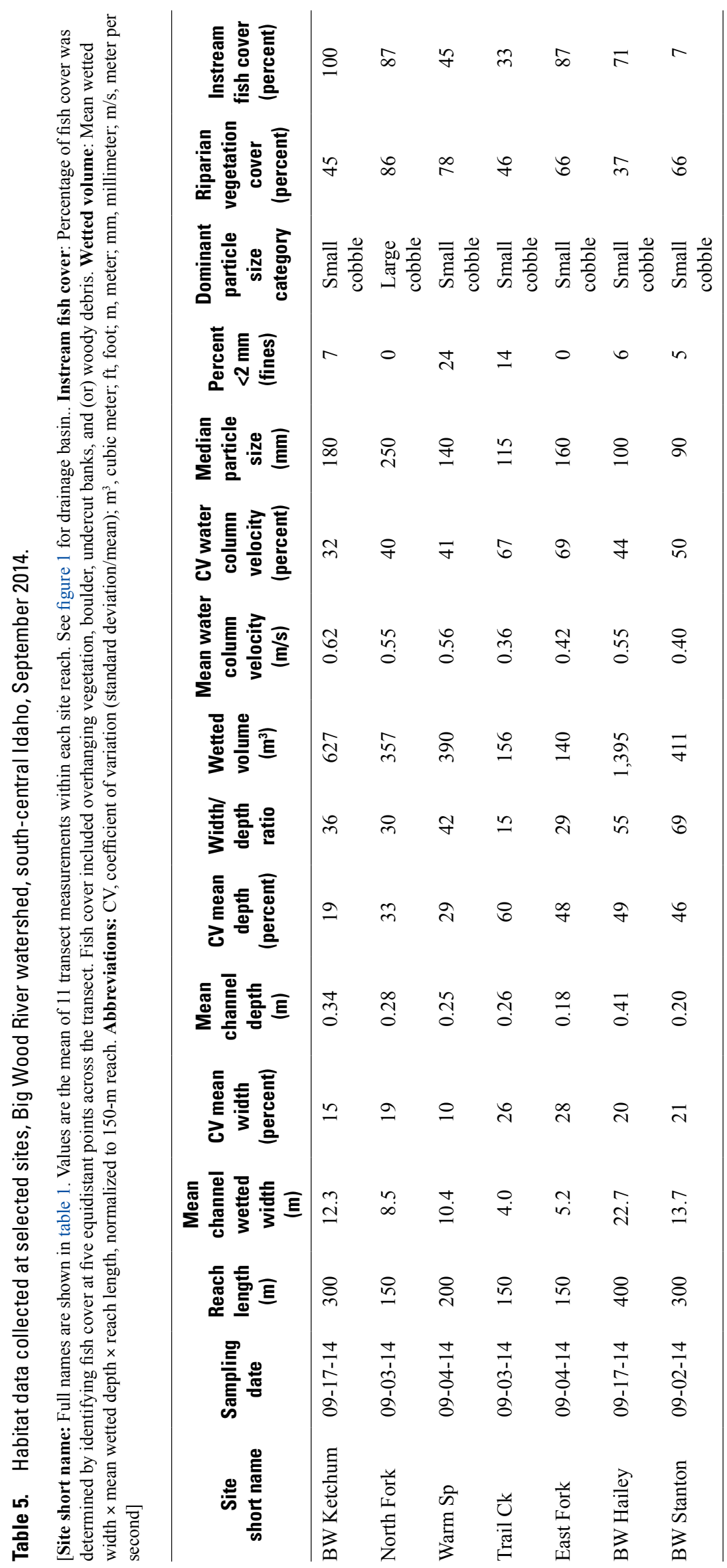




\section{Biological Communities}

\section{Macroinvertebrates}

The number of aquatic insect taxa (EPT) is commonly used as an indicator of water-quality and biological condition, with decreasing EPT values indicating a loss of species that are generally sensitive to environmental degradation. EPT richness was highest at sites in the upper drainage at the North Fork tributary and BW Ketchum (33 and 24 EPT taxa respectively), and generally decreased downstream with the lowest number of EPT taxa with 7 observed at BW Stanton (table 6). The relative contributions of individual taxonomic groups to the overall EPT richness for each site are summarized in figure 6 . Although stream-health standards based on EPT values are not well-defined and vary among environmental settings, an assessment of macroinvertebrate communities in Idaho streams by Maret and others (2001) reported an average EPT value of 18 for systems that were relatively undisturbed by human-caused perturbations. During the Maret study (1996-98), BW Stanton had an EPT value of 16 and at the time was considered relatively unimpaired.

Designation of a cold-water stream is partly based on the presence of organisms that have relatively narrow thermal requirements for growth and reproduction and where cold-water environments are an inherent part of their life-history strategy (U.S. Environmental Protection Agency, 2012). Low abundance or absence of macroinvertebrate species that are limited in their distributions to cold-water streams are indications that streams may be warming. Development of temperature optima for macroinvertebrates in Idaho streams will facilitate temperature-based designations of Idaho streams and rivers and help identify impaired systems (Richards and others, 2013). Macroinvertebrate taxa that occur in the 95th percentile of Idaho streams with water temperatures below $20^{\circ} \mathrm{C}$ were used to identify

Table 6. Macroinvertebrate metrics calculated from samples collected at selected sites in the Big Wood River watershed, south-central Idaho, September 2014.

[Short site name: Full site names are in table 1. Abundance weighted tolerance: Tolerance values from Carlisle and others (2007). FSBI: Fine Sediment Biotic Index; score is the sum of corresponding invertebrate grouping values presented in Reylea and others (2012). Cold-water taxa: Cold water species derived from Richards and others (2013). Simpson's D: Diversity index, scored 0-1, with values closer to 1 with higher diversity. Abbreviations: EPT, ephemeroptera, plecoptera, trichoptera; organisms $/ \mathrm{m}^{2}$, organisms per square meter; mg/L, milligram per liter; PPBV, plains, plateaus, and broad valleys; RD, richness and density ratio; SMI, stream macroinvertebrate index (Tetra Tech, 2011); ${ }^{\circ} \mathrm{C}$, degree Celsius]

\begin{tabular}{|c|c|c|c|c|c|c|c|c|c|}
\hline \multirow{2}{*}{$\begin{array}{l}\text { Site short } \\
\text { name }\end{array}$} & \multirow{2}{*}{$\begin{array}{l}\text { Sample } \\
\text { collection } \\
\text { date }\end{array}$} & \multirow{2}{*}{$\begin{array}{c}\text { Taxa } \\
\text { richness }\end{array}$} & \multirow{2}{*}{$\begin{array}{c}\text { EPT } \\
\text { richness }\end{array}$} & \multirow{2}{*}{$\begin{array}{c}\text { Density } \\
\text { (organisms/m²) }\end{array}$} & \multirow{2}{*}{\multicolumn{2}{|c|}{$\begin{array}{l}\text { Natural log richness/ } \\
\text { natural log density } \\
\text { (RD) }\end{array}$}} & \multicolumn{3}{|c|}{ Cold-water taxa } \\
\hline & & & & & & & \multicolumn{2}{|l|}{ Number } & Percent \\
\hline BW Ketchum & $09-17-14$ & 40 & 24 & 1,869 & \multicolumn{2}{|r|}{0.49} & \multicolumn{2}{|l|}{19} & 40 \\
\hline North Fork & $09-03-14$ & 51 & 33 & 1,379 & \multicolumn{2}{|r|}{0.55} & \multicolumn{2}{|l|}{26} & 50 \\
\hline Warm Sp & 09-04-14 & 36 & 12 & 1,816 & \multicolumn{2}{|r|}{0.47} & \multicolumn{2}{|l|}{6} & 2 \\
\hline Trail Ck & 09-03-14 & 40 & 12 & 1,687 & \multicolumn{2}{|r|}{0.50} & \multicolumn{2}{|l|}{10} & 25 \\
\hline East Fork & $09-03-14$ & 45 & 18 & 4,508 & \multicolumn{2}{|r|}{0.46} & \multicolumn{2}{|l|}{11} & 24 \\
\hline BW Hailey & $09-17-14$ & 34 & 8 & 3,386 & \multicolumn{2}{|r|}{0.43} & \multicolumn{2}{|l|}{4} & 12 \\
\hline BW Stanton & $09-02-14$ & 23 & 7 & 7,797 & \multicolumn{2}{|r|}{0.35} & 0 & & 0 \\
\hline & & Abundar & nce weighted t & tolerance & & & & & \\
\hline $\begin{array}{l}\text { Site short } \\
\text { name }\end{array}$ & $\begin{array}{l}\text { Sample } \\
\text { collection } \\
\text { date }\end{array}$ & Nutrients & $\begin{array}{c}\text { Water } \\
\text { temperature } \\
\left({ }^{\circ} \mathrm{C}\right)\end{array}$ & $\begin{array}{l}\text { Suspended domi } \\
\text { sediment } \\
(\mathrm{mg} / \mathrm{L})\end{array}$ & $\begin{array}{l}\text { Three } \\
\text { inant taxa } \\
\text { ercent) }\end{array}$ & $\begin{array}{c}\text { Simpson's } \\
\text { D }\end{array}$ & $\begin{array}{l}\text { PPBV } \\
\text { SMI2 }\end{array}$ & $\begin{array}{l}\text { lountains } \\
\text { SMI2 }\end{array}$ & FSBI \\
\hline BW Ketchum & $09-17-14$ & 3.8 & 3.0 & 3.5 & 46 & 0.90 & 85 & 63 & 190 \\
\hline North Fork & $09-03-14$ & 3.3 & 2.5 & 3.4 & 44 & 0.91 & 79 & 77 & 210 \\
\hline Warm Sp & 09-04-14 & 5.7 & 4.2 & 5.5 & 49 & 0.90 & 78 & 37 & 70 \\
\hline Trail Ck & $09-03-14$ & 6.1 & 2.9 & 4.7 & 56 & 0.83 & 73 & 37 & 80 \\
\hline East Fork & 09-03-14 & 6.2 & 2.8 & 4.2 & 43 & 0.91 & 70 & 47 & 90 \\
\hline BW Hailey & $09-17-14$ & 4.2 & 2.8 & 3.9 & 51 & 0.85 & 71 & 30 & 75 \\
\hline BW Stanton & 09-02-14 & 7.7 & 6.6 & 8.5 & 92 & 0.22 & 71 & 11 & 35 \\
\hline
\end{tabular}




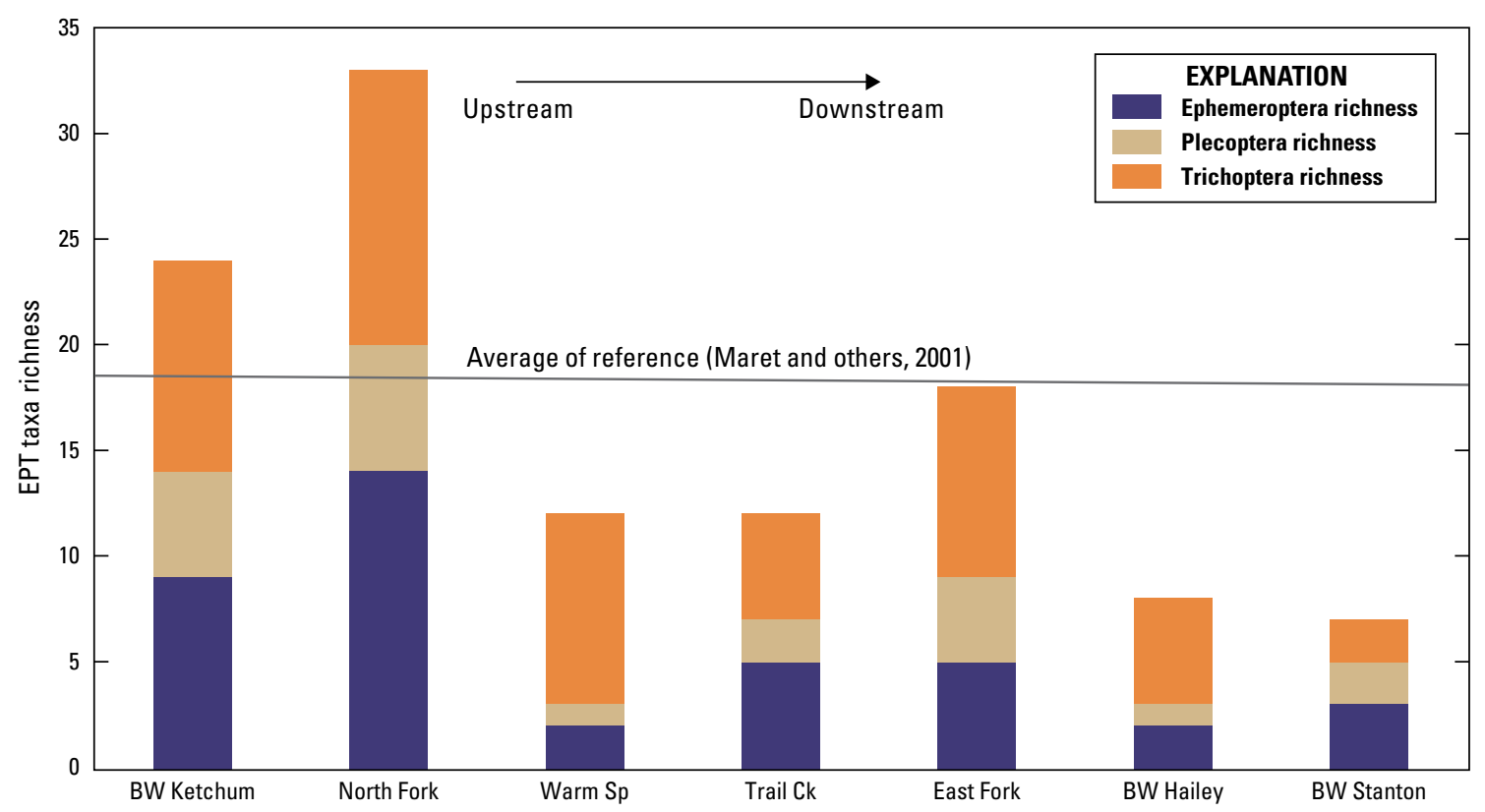

Figure 6. Ephemeroptera, plecoptera, and trichoptera (EPT) taxa richness from samples collected at selected sites in the Big Wood River watershed, south-central Idaho, September 2014. Full site names are shown in table 1.

cold-water taxa collected as part of this investigation.

Thirty-three cold-water macroinvertebrate taxa were found among the tributary and main-stem sites of the Big Wood River, 13 of which consisted of mayfly, stonefly, and caddisfly taxa (appendix A). The highest numbers of coldwater macroinvertebrate taxa (19 and 26, respectively) were collected at the BW Ketchum and North Fork sites. Macroinvertebrate community samples collected at BW Hailey and at the Warm Sp, Trail Ck, and East Fork sites each contained less than 12 cold-water macroinvertebrate taxa. No macroinvertebrates designated as cold-water species were collected at BW Stanton.

Although occurrence patterns of cold-water macroinvertebrate taxa may be an indication of stream thermal properties, it is recognized that stream organisms integrate stressor effects from multiple sources that typically act in concert to affect stream communities. For streams in the Big Wood River watershed, effects from groundwater and surface water abstraction, nutrient enrichment, elevated stream temperatures, and increased sediment loading collectively, can potentially influence local biological condition to varying degrees depending on adjacent land-use and water management practices in the watershed. To examine different stressor effects, macroinvertebrate community tolerances to nutrient enrichment, elevated water temperature, and high concentrations of suspended sediment were used to determine whether sites in the Big Wood River watershed may be subject to one or more physical or chemical perturbations affecting water-quality and overall stream health. Despite the fact that nutrient concentrations were not markedly elevated in stream water (table 3), tolerance values for macroinvertebrates sensitive to nutrient enrichment indicated that water-quality at the East Fork and Trail Ck tributaries, and at BW Stanton, may be subject to some levels of nutrient enrichment or other forms of organic pollution (fig. 7). Macroinvertebrate community responses to enrichment represent a time-integrated effect likely occurring over an exposure period of weeks or months, and may not be consistent with results of water-quality determinations based on a single sampling event.

Relative abundances of temperature tolerant macroinvertebrate taxa were low at most sites, except for Warm Sp and BW Stanton (table 6, fig. 7). Higher temperature tolerance values for macroinvertebrate communities at these sites corresponded to mean summer water temperatures (May to September), which were the highest (15.5 and $15.6^{\circ} \mathrm{C}$, respectively) among the study sites (table 4). Additionally, Warm Sp and BW Stanton both experienced temperature exceedances of $22{ }^{\circ} \mathrm{C}$ during the summer months (table 4).

Elevated levels of suspended sediment are a naturally occurring event in most stream systems and, accordingly, stream macroinvertebrates as a group are relatively tolerant of periodic increases in SSC (Ward, 1992). Although SSC were low at all sites during the September 2014 water-quality 


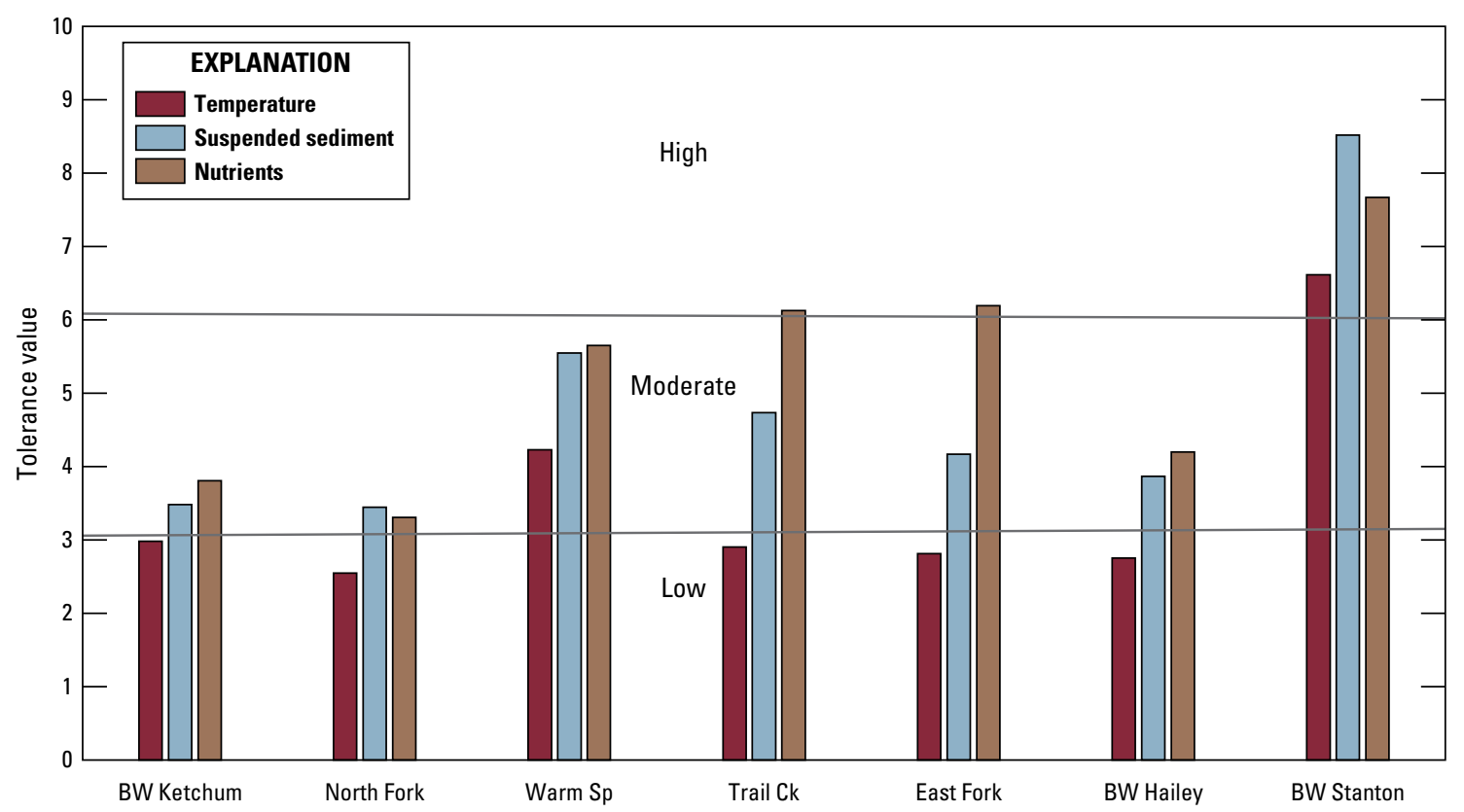

Figure 7. Temperature, suspended sediment, and nutrient tolerance values for invertebrates at selected sites, Big Wood River, south-central Idaho.

assessment (table 3), suspended-sediment tolerance values were high at BW Stanton (8.5) compared to other sites in the drainage (values ranging from 3.4 to 5.5) (fig. 7, table 6). Given the lack of long-term water quality monitoring data for these locations, responses of macroinvertebrate communities to these multiple stressors can only be inferred, and may be part of a more generalized response to a broader array of environmental conditions. Nevertheless, elevated tolerance values for macroinvertebrate communities at BW Stanton suggest the likelihood of some impairment caused by stream conditions. Species diversity index values (Simpson's D) were high $(>0.80)$ among tributary and main-stem sites of the Big Wood River except BW Stanton (0.22) (table 6). Diversity index values increase as the abundance of individual taxa of the entire community assemblage becomes more equitable (Magurran, 1988). The low diversity index value $(0.22)$ at BW Stanton compared to the other study sites is a result of relatively low species richness (22) and high macroinvertebrate density $\left(7,797\right.$ organisms $\left./ \mathrm{m}^{2}\right)$. These relations are exemplified in the comparisons of species RD shown in table 6 , which provides an indication of relative evenness between the numbers and kinds of taxa at a sampling location. Richness-density ratios were highest for macroinvertebrate communities at the North Fork tributary $(\mathrm{RD}=0.55)$ and lowest for communities at BW Stanton $(\mathrm{RD}=$ 0.35 ). The low RD and diversity values at BW Stanton were largely a result of the numerical dominance of the generally tolerant caddisfly Hydropsyche spp., which comprised 88 percent of the total macroinvertebrate density at that location (appendix A). The decrease and periodic loss of channel connectivity (Bartolino, 2014) and presumably upstream recruitment pools caused by flow alterations may partly be responsible for the relatively low number of taxa at the BW Stanton site.

The Idaho State SMI2 values calculated for the Big Wood River and tributary sites all were within the reference range for the PPBV ecoregion (50 and 94, table 6). The Mountains ecoregion SMI2 values were outside the reference range (33 and 94) at BW Hailey (Mountains SMI2 = 30) and BW Stanton (Mountains SMI2 = 11; Jason Pappani, Idaho Department of Environmental Quality, written commun., October 2015; table 6). The combination of metrics that are used for calculating the SMI2 collectively do not appear to be as sensitive as the individual abundance weighted tolerance values and diversity metrics in identifying potential effects to stream invertebrates for sites in the Big Wood River watershed. However, a multi-metric index of this type is inherently more robust than single metric indices and, as such, is often more representative of overall stream health. Moreover, it is important to note that the scoring criteria of the SMI2 for PPBV and Mountains IDEQ ecoregions has not been finalized as of 2016 and that the index may undergo additional refinement. 
The Fine Sediment Biotic Index (FSBI) is designed as a stressor-specific biomonitoring index to assess fine sediment impacts on macroinvertebrate communities, with higher index values indicating greater abundance of more sediment-sensitive taxa and, by inference, better water-quality conditions. The highest FSBI values were at the BW Ketchum and the North Fork sites, and the lowest FSBI value occurred at BW Stanton (table 6), with the macroinvertebrate community at BW Stanton consisting of comparatively higher densities of fine-sediment tolerant taxa. The FSBI values for the Big Wood River main-stem and tributary sites were consistent with suspended-sediment tolerance values in terms of characterizing general patterns of macroinvertebrate sediment sensitivity. Ultimately, the SMI2 and FSBI will be used to evaluate beneficial use designations for streams in the Big Wood River watershed (Tetra Tech, 2011).

\section{Fish}

The Big Wood River and tributaries provide habitat for native Catostomidae (bridgelip sucker), Cyprinidae (redside shiner, longnose dace and speckled dace), Salmonidae (rainbow trout and mountain whitefish), and Cottidae (Wood River sculpin). Introduced species include brook trout and brown trout (appendix B). Although introduced brook trout and brown trout often are considered desirable in supporting local recreational fisheries, when abundant they have the potential to alter habitat suitability for native species and diminish food resource availability. Of concern to the health of the native fishery is that as streams and rivers become altered as a result of land- and water-use practices, potential loss of habitat and biological complexity favors proliferation of more tolerant non-native and invasive species (Peipoch and others, 2015). Fish surveys in September 2014 determined that occurrence of non-native species was limited to sites on the main stem of the Big Wood River (appendix B). Non-native brook trout and brown trout were observed at BW Hailey, but both occurred in relatively low numbers ( 0.6 and 4.7 percent of fish relative abundance, respectively). Brown trout were the only non-native fish collected at BW Stanton, but were present in somewhat higher numbers (14.6 percent of the total fish abundance). Typical for many relatively undisturbed Western streams (Whittier and others, 2007), the total number of fish taxa was generally low overall with three or fewer species collected at BW Ketchum, North Fork, Trail Ck, and East Fork. The highest numbers of fish species were collected at Warm Sp (five), BW Hailey (four), and BW Stanton (six). Native rainbow and brown trout and Wood River sculpin were the dominant fish species in the drainage and were found at all tributary and main-stem sites (figs. 8 and 9).

Fish size (length and weight) has been shown to be a good indicator of fish health, where low weight-to-length ratios are indicative of potential impairment of health and overall well-being (Anderson and Gutreuter, 1983). Indices of fish condition that rely on size parameters, such as the condition coefficient $(\mathrm{K})$, are commonly used as diagnostic measures of fish condition (Williams, 2000). The IDFG uses several different measures for evaluating fish condition that include examination of relative weight and age-related growth (Idaho Department of Fish and Game, 2013). Fish population data from the September 2014 survey alone are not sufficient to quantitatively assess fish health for the Big Wood River and tributaries; however, fish collected as part of this study appeared in good health at all sampling locations, with few if any instances of external anomalies (deformities, eroded fins, lesions, and tumors) that might be indicative of environmental stress. These observations are consistent with earlier studies that considered the Big Wood River to be of high biotic integrity (Maret, 1997; Mebane and others, 2003).

Although preliminary SFI2 values for the Big Wood River sites (appendix B) were within the range of reference values for the PPBV (61-100) and Mountains (30-100), between-site differences in index values were not great enough to indicate any potential effect to the fishery. The State of Idaho is finalizing scoring criteria for the SFI2 to help refine designated site use attainability.

The strong positive relation between fish production and fluvial habitat availability (as estimated by WV) attests to the importance of preserving as best as possible natural flow regimes for streams and rivers in the Big Wood River watershed. Among all study sites, fish biomass (total weight of all fish normalized to a reach length of $150 \mathrm{~m}$ ) was strongly correlated with wetted volume ( $r h o=0.86$, $P=0.006)$, with the highest fish biomass and wetted volume occurring at BW Hailey (table 5; appendix B). In comparison, owing to reduced discharge, wetted volume at BW Stanton was 29 percent of that upstream at BW Hailey, and, correspondingly, fish biomass was 25 percent of that at BW Hailey. 


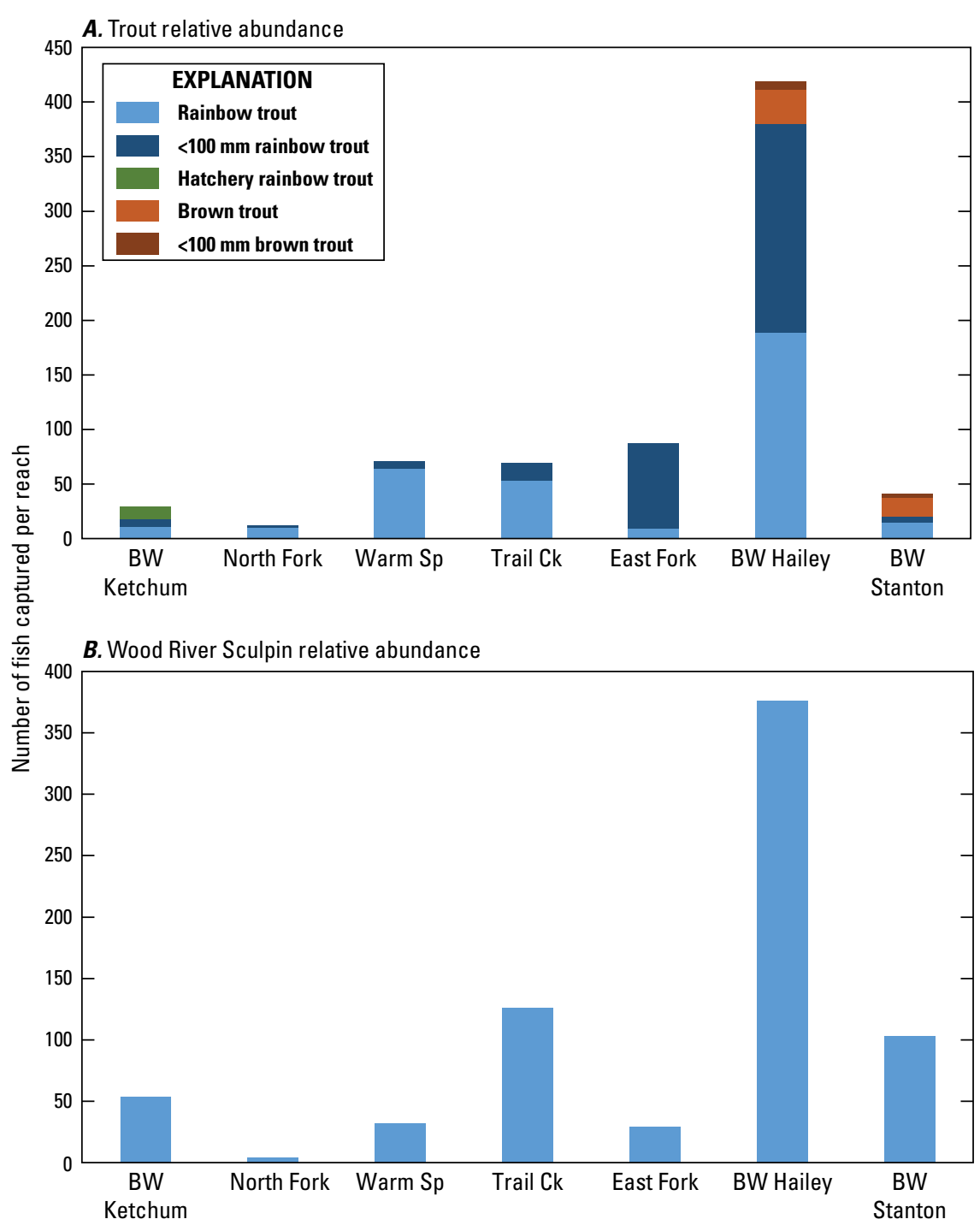

Figure 8. Trout and Wood River sculpin (Cottus leiopomus) relative abundance from samples collected at sites in the Big Wood River watershed, south-central Idaho, September 2014. Full site names are shown in table 1.

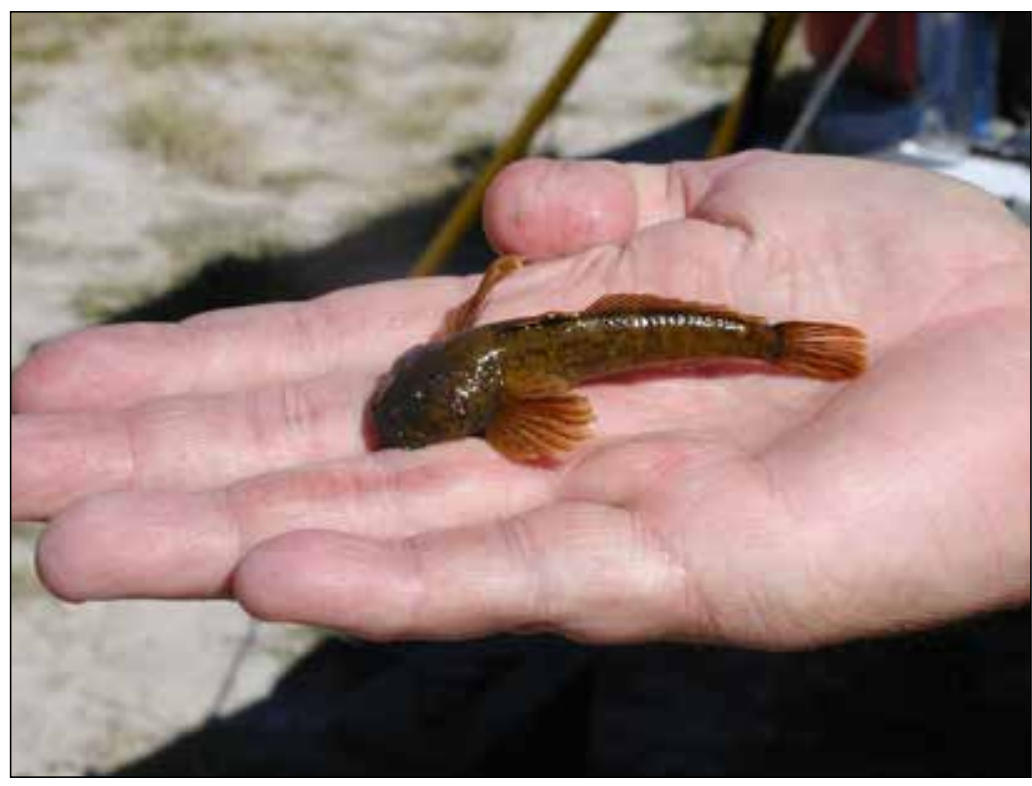

Figure 9. Wood River sculpin (Cotus leiopomus). Photograph by Don Zaroban, Orma J. Smith Museum of Natural Science, Caldwell, Idaho. 


\section{Summary}

Land-use development and population growth will likely play an increasingly important role in affecting the quality of freshwater resources in the Big Wood River watershed. Increased demands on surface water and groundwater resources pose a serious challenge to long-term water management and resource conservation strategies in the watershed. Fundamental to meeting this challenge is establishing scientifically sound water quality and biological monitoring programs to support informed management decisions. Results presented here are a synopsis of existing key physical, chemical, and biological properties of the Big Wood River and its major tributaries. This information provides a basis with which to evaluate and monitor the long-term health of surface-water resources in the Big Wood River watershed. Natural flows are characterized by temporal and spatial variability in the magnitude, frequency, and duration of discharge. The occurrence and distribution of fish and macroinvertebrates in the Big Wood River and its tributaries are determined in part by these flow parameters. Comparison of daily discharge patterns for water years 2012-15 for sites on the Big Wood River showed that flow magnitude increased downstream from BW Ketchum to BW Hailey, but decreased from BW Hailey to BW Stanton by more than half during this period.

Annual and seasonal flow variability for the Big Wood River increased in a downstream direction with the highest variability observed at BW Stanton. Reduced and more variable summer flows (46 percent) occurring at BW Stanton likely result from flow diversions downstream of the City of Bellevue to support increased agriculture demands during the summer months. With the exception of BW Stanton, annual variability of daily mean flows among tributary and main-stem sites was generally low (ranging between 17 to 33 percent), and probably reflect naturally occurring seasonal changes in streamflow.

Examination of annual base-flow index values for sites on the Big Wood River and tributaries showed that groundwater contributes greater than 85 percent of the total flow during late summer, when streamflow is typically at its lowest and when conditions are often most stressful to aquatic organisms. Groundwater discharge is particularly important in moderating stream temperature extremes, which is critical to maintaining a cold-water fishery in the Big Wood River. During August 2014 , decreases in groundwater contributions to total discharge were evident only at Trail Ck (36 percent of total flow) and BW Stanton (13 percent of total flow). Increased surface-water contributions to total discharge at these sites may have resulted from late summer rainfall in the Trail Ck drainage and from irrigation return flows for BW Stanton.

Among the Big Wood River and tributary sites, the highest mean daily water temperatures for June-September 2014 occurred at Warm Sp $\left(15.5^{\circ} \mathrm{C}\right)$ and BW Stanton $\left(15.6{ }^{\circ} \mathrm{C}\right)$. The presence of greater numbers of high temperature tolerant invertebrate taxa at these locations is consistent with the temperature findings. Additionally, the State of Idaho maximum temperature criterion for the protection of cold-water aquatic life of $22{ }^{\circ} \mathrm{C}$ was exceeded at both these locations during the period from June to August, but at none of the other study sites. The critical temperature criterion for salmonid spawning of $13{ }^{\circ} \mathrm{C}$ was exceeded in early July 2014 at both BW Ketchum and BW Hailey near the end of the rainbow trout critical period. Spawning temperature exceedances were most frequent at BW Stanton where exceedances for both rainbow and brown trout were observed from May through July during most of the critical periods for both species.

Water-quality assessments in September 2014 determined no direct evidence of water-quality impairment resulting from elevated concentrations of suspended sediment or nutrients. Suspended sediment and nutrient concentrations were generally low in streams throughout the watershed and within the accepted TMDL water-quality guidelines. Absence of organic enrichment for the Big Wood River and tributaries was also evident by the presence of low concentrations of algal biomass. Similarly, fecal indicator analysis concluded that concentrations of $E$. coli were well within TMDL target levels at all sites. Despite the fact that nutrient concentrations were not elevated in stream water, tolerance values for macroinvertebrates sensitive to nutrient enrichment indicated that water quality at the East Fork and Trail Ck sites and at BW Stanton may be periodically subject to some nutrient enrichment or other forms of organic pollution. Macroinvertebrate responses to enrichment are based on exposure periods of weeks to months and may not be consistent with results from water-quality assessments based on a single sampling event. Observed biological responses may be indicative of possible enrichment occurrences prior to the September 2014 water-quality sampling. Relatively high suspended-sediment tolerance values also were determined for macroinvertebrate communities at BW Stanton in contrast to other sites in the drainage. Given the lack of long-term water-quality monitoring data for sites on the Big Wood River and tributaries, responses of macroinvertebrate communities to nutrient, suspended sediment, and temperature stressors can only be inferred, and may be part of a more generalized response to a broader array of environmental conditions. Nevertheless, high tolerance values for macroinvertebrate communities at BW Stanton suggest some impairment of biological condition and decline in stream health at that site.

Habitat availability and quality did not seem to be limiting for fish or other organisms at sites on the Big Wood River and tributaries with the exception of BW Stanton. Lower wetted volume and high width-to-depth ratio at BW Stanton compared to the other main-stem sites are indicative of relatively shallowwater habitat conditions that may result in low fish abundances. Indeed, fish biomass at BW Stanton was only 25 percent of that upstream at BW Hailey. Additionally, the amount of instream structure and other features that provide needed refuge for fish and other organisms was severely lacking at the BW Stanton site, and comprised only 7 percent of the total possible cover availability compared to 100 and 71 percent for BW Ketchum and BW Hailey, respectively. 
For streams within the Big Wood River watershed, potential effects from groundwater and surface water abstraction, nutrient enrichment, elevated stream temperatures and increased sediment loading collectively influence local biological conditions. Biological communities integrate disturbance effects from multiple sources and species-specific responses provide a means with which to assess the relative contribution of individual stressors to overall health of the system. Numbers of stressor sensitive macroinvertebrate EPT taxa were highest in the upper drainage on the North Fork and BW Ketchum (31 and 24 EPT taxa, respectively), and generally decreased downstream with the lowest number of EPT taxa (7 EPT taxa) observed at BW Stanton. The EPT richness at BW Stanton in September 2014 was less than one-half that in a 1998 study of biological integrity for Idaho streams. High macroinvertebrate diversity index values ( $>0.80$ for Simpson's D) are generally indicative of a healthy stream environment. Macroinvertebrate diversity values for tributary and main-stem sites ranged from 0.83 to 0.91 except for BW Stanton with a diversity value of 0.22 . The low diversity index value for macroinvertebrate communities at BW Stanton was a result of relatively low taxa richness and high abundances of a few taxa, in particular the caddisfly (Hydropsyche spp.), which was the most numerically dominant taxa. The reduction and periodic loss of channel connectivity and presumably upstream recruitment pools as a result of flow alterations may in part be responsible for the relatively low number of macroinvertebrate taxa observed at the BW Stanton site.

Native fish communities are one of the most important assets to the Big Wood River and its tributaries. Alteration of natural flow regimes in the Big Wood River watershed can potentially result in a loss of habitat and biological complexity that favors proliferation of non-native and invasive species, and ultimately lead to a reduction in the number of native species and overall fish health. Fish surveys conducted in September 2014 did not find any significant decrease in occurrence of native fish communities in the Big Wood River or its tributaries. Native rainbow trout and Wood River sculpin were the dominant fish species in the drainage and were found at all tributary and main-stem sites. Additionally, fish communities at all sites appeared to be in relatively good health with few instances of external anomalies or diminished size that might be indicative of environmental stress.

The September 2014 assessments of macroinvertebrate and fish communities represent a single sampling period and, as such, do not provide information on intrinsic variability (seasonal and annual changes) in community assemblages; therefore, there was not enough information to effectively calculate and compare biological metrics using the Idaho State macroinvertebrate (SMI2) and fish indices (SFI2). However, the biological indices are valuable tools that can be used to assess the ecological condition and health of stream resources in the Big Wood River watershed; the information in this report will contribute to that effort.

\section{References Cited}

Allan, J.D., 1995, Stream Ecology—Structure and function of running waters: Norwell, Massachusetts, Kluwer Academic Publishers, $388 \mathrm{p}$.

American Society for Testing and Materials, 2002, Standard test methods for determining sediment concentration in water samples, method \#ASTM D3977-97: American Society for Testing and Materials, accessed July 28, 2015, at http://www.astm.org/Standard/index.shtml.

Anderson, R.O., and Gutreuter, S.J., 1983, Length, weight, and associated structural indices, in Nielsen, L., and Johnson, D., eds., Fisheries techniques: Bethesda, Maryland, American Fisheries Society, p. 284-300.

Bartolino, J.R., 2009, Ground-water budgets for the Wood River Valley aquifer system, south-central Idaho, 19952004: U.S. Geological Survey Scientific Investigations Report 2009-5016, 36 p. [Also available at http://pubs.usgs. gov/sir/2009/5016/.]

Bartolino, J.R., 2014, Stream seepage and groundwater levels, Wood River Valley, south-central Idaho, 2012-13: U.S. Geological Survey Scientific Investigations Report 20145151, 34 p. [Also available at http://dx.doi.org/10.3133/ sir20145151.]

Bartolino, J.R., and Adkins, C.B., 2012, Hydrogeologic framework of the Wood River Valley aquifer system, south-central Idaho: U.S. Geological Survey Scientific Investigations Report 2012-5053, 46 p. [Also available at http://pubs.usgs.gov/sir/2012/5053/.]

Biggs, B.J.F., 2000, Eutrophication of streams and riversDissolved nutrient-chlorophyll relationships for benthic algae: Journal of the North American Benthological Society, v. 19 , p. 17-31.

Biggs, B.J.F., and Close, M.E., 1989, Periphyton biomass dynamics in gravel bed rivers-The relative effects of flows and nutrients: Freshwater Biology, v. 22, p. 209-231.

Brown, L.W., Milner, A.M., and Hannah, D.M., 2007, Groundwater influence on alpine stream ecosystems: Freshwater Biology, v. 52, p. 878-890.

Buhidar, B.B., 2002, The Big Wood River watershed management plan: Twin Falls, Idaho Department of Environmental Quality, 177 p., accessed June 2, 2015, at http://www.deq.idaho.gov/media/450316-_water_data reports_surface_water_tmdls_big_wood_river_big_wood_ entire.pdf. 
Carlisle, D.M., Meador, M.R., Short, T.M., Tate, C.M., Gurtz, M.E., Bryant, W.L., Falcone, J.A., and Woodside, M.D., 2013, The quality of our Nation's waters-Ecological health in the Nation's streams, 1993-2005: U.S. Geological Survey Circular 1391, 120 p. [Also available at http://pubs.usgs. gov/circ/1391/.]

Castelin, P.M., and Chapman, S.L., 1972, Water resources of the Big Wood River-Silver Creek area, Blaine County, Idaho: Boise, Idaho Department of Water Administration, Water Information Bulletin 28, 44 p., accessed August 8, 2013, at http://www.idwr.idaho.gov/WaterInformation/ Publications/wib/wib28-big_wood_river-silver_creek_area. pdf.

Clow, D.W., 2008, Changes in the timing of snowmelt and streamflow in Colorado-A response to recent warming: Journal of Climate, v. 23, p. 2,293-2,306, accessed September 17, 2015, at http://co.water.usgs.gov/ publications/non-usgs/Clow2010_SnowmeltTiming.pdf.

Constantz, J., Thomas, C.L., and Zellweger, G., 1994, Influence of diurnal variations in stream temperature on streamflow loss and groundwater recharge: Water Resources Research, v. 30, p. 3,253-3,264.

Cuffney, T.F., and Brightbill, R.A., 2011, User's manual for the National Water-Quality Assessment Program Invertebrate Data Analysis System (IDAS) software, version 5: U.S. Geological Survey Techniques and Methods 7-C4, 126 p. [Also available at http://pubs.usgs.gov/tm/7c4/.]

Cummins, K.W., 1979, The natural stream ecosystem, in Ward, J.V., and Stanford, J.A., eds., The ecology of regulated streams: New York, Plenum, p. 7-24.

Dodds, W.K., and Welch, E.B., 2000, Establishing nutrient criteria in streams: Journal of the North American Benthological Society, v. 19, p. 186-196.

Doyle, M.W., Stanley, E.H., Strayer, D.L., Jacobson, R.B., and Schmidt, J.C., 2005, Effective discharge analysis of ecological processes in streams: Water Resources Research, v. 41, p. $1-16$.

Dubrovsky, N.M., Burrow, K.R., Clark, G.M., Gronberg, J.M., Hamilton, P.A., Hitt, K.J., Mueller, D.K., Munn, M.D., Nolar, B.T., Puckett, L.J., Rupert, M.G., Short, T.M., Spahr, N.E., Sprague, L.A., and Wilber, W.G., 2010, The quality of our Nation's waters-Nutrients in the Nation's streams and groundwater, 1992-2004: U.S. Geological Survey Circular 1350, 174 p. [Also available at http://pubs.usgs. gov/circ/1350/.]

Eaton, A.D., Clesceri, L.S., and Greenberg, A.E., 1999, Standard methods for the examination of water and wastewater, 20th ed.: Washington, D.C., American Public Health Association, variously paged.
Ferreira, M.T., Franco, A., Catarino, L., Moreira, I., and Sousa, P., 1999, Environmental factors related to the establishment of algal mats in concrete irrigation channels: Hydrobiologia, v. 415 , p. $163-168$.

Findlay, S., 1995, Importance of surface-subsurface exchange in stream ecosystems-The hyporheic zone: Limnology and Oceanography, v. 40, p. 159-164.

Fishman, M.J., 1993, Methods of analysis by the U.S. Geological Survey National Water-Quality LaboratoryDetermination of inorganic and organic constituents in water and fluvial sediments: U.S. Geological Survey OpenFile Report 93-125, 217 p. [Also available at http://pubs. er.usgs.gov/publication/ofr93125.]

Fitzpatrick, F.A., Waite, I.R., D’Arconte, P., Meador, M.R., Maupin, M.A., and Gurtz, M.E., 1998, Revised methods for characterizing stream habitat in the National WaterQuality Assessment Program: U.S. Geological Survey Water Resources Investigation Report 98-4052, 67 p. [Also available at http://pubs.usgs.gov/wri/wri984052/.]

Foley, D., and Street, L., 1988, Hydrothermal systems of the Wood River area, Idaho, in Link, P.K., and Hachette, W.R., eds., Guidebook to the geology of central and southern Idaho: Idaho Geology Survey Bulletin 27, p. 109-126, http://www.idahogeology.org/Products/reverselook.asp?sw itch=title\&value=Guidebook_to_the_Geology_of_Central_ and_Southern_Idaho.

Forstall, Richard, ed., 1995, Idaho population of counties by decennial census - 1900 to 1990: U.S. Census Bureau, accessed July 27, 2015, at http://www.census.gov/ population/cencounts/id190090.txt.

Friedman, L.C., and Erdmann, D.E., 1982, Quality assurance practices for the chemical and biological analyses of water and fluvial sediments: U.S. Geological Survey Techniques of Water-Resources Investigations, book 5, chap. A6, 181 p.

Gordon, N.D., McMahon, T.A., and Finlayson, B.L., 1993, Stream hydrology-An introduction for ecologists: John Wiley \& Sons, New York, 526 p.

Grafe, C.F., ed., 2002a, Idaho River ecological assessment framework: Idaho Department of Environmental Quality, accessed July 27, 2015, at http://www.deq.idaho.gov/ media/457032-assessment_river_entire.pdf.

Grafe, C.F., ed., 2002b, Idaho small stream ecological assessment framework: Idaho Department of Environmental Quality, accessed July 27, 2015, at http://www.deq.idaho. gov/media/457038-assessment_stream_entire.pdf.

Guy, H.P., 1969, Laboratory theory and methods for sediment analysis: U.S. Geological Survey Techniques of Water Resources Investigations, book 5, chap. C1, 58 p. [Also available at http://pubs.usgs.gov/twri/twri5c1.] 
Hardy, M.A., Parliman, D.J., and O'Dell, I., 2005, Status of and changes in water-quality monitored for the Idaho Statewide Surface-Water-Quality Network, 1989-2002: U.S. Geological Survey Scientific Investigations Report 2005-5033, 66 p. plus 3 apps. http://pubs.er.usgs.gov/ publication/sir20055033.

Homer, C.G., Dewitz, J.A., Yang, L., Jin, S., Danielson, P., Xian, G., Coulston, J., Herold, N.D., Wickham, J.D., and Megown, K., 2015, Completion of the 2011 National Land Cover Database for the conterminous United StatesRepresenting a decade of land cover change information: Photogrammetric Engineering and Remote Sensing, v. 81, no. 5, p. 345-354, accessed December 30, 2015, at http:// www.mrlc.gov/nlcd2011.php.

Hopkins, C.B., and Bartolino, J.R., 2013, Quality of groundwater and surface water, Wood River Valley, southcentral Idaho, July and August 2012: U.S. Geological Survey Scientific Investigations Report 2013-5163, 32 p. [Also available at http://pubs.usgs.gov/sir/2013/5163.]

Hortness, J.E., and Berenbrock, C., 2003, Estimating the magnitude of bankfull flows for streams in Idaho: U.S. Geological Survey Water-Resources Investigations Report 2003-4261, 37 p. [Also available at http://pubs.er.usgs.gov/ publication/wri034261.]

Idaho Department of Environmental Quality, 2013, Big Wood River tributaries temperature total maximum daily loads, 2013 addendum: Idaho Department of Environmental Quality Web site, accessed July 27, 2015, at http://www. deq.idaho.gov/media/1068712-big_wood_river_tributaries_ temperature_tmdl_addendum_2013.pdf.

Idaho Department of Environmental Quality, 2014, Beneficial use reconnaissance program 2014 annual work plan: Idaho Department of Environmental Quality, accessed July 27, 2015, at http://www.deq.idaho.gov/media/1118651/burpwork-plan-2014.pdf.

Idaho Department of Environmental Quality, 2015, Idaho's water-quality standards, IDAPA 58.01.02: Idaho Department of Environmental Quality Web site, accessed November 17, 2015, at https://www.deq.idaho.gov/waterquality/surface-water/standards/.

Idaho Department of Environmental Quality, 2016, Beneficial use reconnaissance program: Idaho Department of Environmental Quality Web site, accessed April 15, 2016, at http://www.deq.idaho.gov/water-quality/surface-water/ monitoring-assessment/burp/.

Idaho Department of Fish and Game, 2013, Fisheries Management Plan 2013-2018-A comprehensive guide to managing Idaho's Fisheries Resources: Idaho Department of Fish and Game Web site, accessed July 27, 2015, at http:// fishandgame.idaho.gov/public/fish/planFisheries.pdf.
Jones, R.P., 1952, Evaluation of streamflow records in the Big Wood River basin, Blaine County, Idaho: U.S. Geological Survey Circular 192, 59 p., 1 pl. in pocket, [Also available at http://pubs.er.usgs.gov/publication/cir192.]

Karr, J.R., 1991, Biological integrity-A long-neglected aspect of water resource management: Ecological Applications, v. 1, no. 1, p. 66-84, http://www.jstor.org/ stable/1941848.

Kaufmann, P.R, Levine, P., Robison, E.G., Seeliger, C., and Peck, D.V., 1999, Quantifying physical habitat in wadeable streams: U.S. Environmental Protection Agency, EPA/620/R-99/003. 102 p., plus apps., http://www.epa.gov/ emap/html/pubs/docs/groupdocs/surfwatr/field/phyhab.pdf.

Knighton, D., 1998, Fluvial forms and processes-A New Perspective: London, Hodder Arnold Publishing, 383 p.

Knott, J.M., Glysson, G.D., Malo, B.A., and Schroeder, L.J., 1993, Quality assurance plan for the collection and processing of sediment data by the U.S. Geological Survey, Water Resources Division: U.S. Geological Survey OpenFile Report 92-499, 18 p.

Konrad, C.P., and Booth, D.B., 2005, Hydrologic changes in urban streams and their ecological significance: American Fisheries Society Symposium 47, p. 157-177.

Lapointe, N.W., Cooke, S.J., Imhof, J.G., Boisclare, D., Casselman, J.M., Curry, R.A., Langer, O.E., McLaughlin, R.L., Minns, C.K., Post, J.R., Power, M., Rasmussen, J.B., Reynolds, J.D., Richardson, J.S., and Tonn, W.M., 2014, Principles for ensuring healthy and productive freshwater ecosystems that support sustainable fisheries: Environmental Review, v. 22, no. 2, p. 110-134, http:// dx.doi.org/10.1139/er-2013-0038.

Leopold, L.B., 1994, A view of the river: Cambridge, Massachusetts, Harvard University Press, 298 p.

Lim, K.J., Engel, B.A., Tang, Z., Choi, J., Kim, K., Muthukrishnan, S., and Tripathy, D., 2005, Automated Web GIS Based Hydrograph Analysis Tool, WHAT: Journal of the American Water Resources Association v. 41, no. 6, p. 1,407-1,416. [Also available at https://engineering.purdue. edu/ what/faq/Automated_Web_GIS_based_Hydrograph_ Analysis_Tool_WHAT_JAWRA_Dec_2005.pdf.]

Lohman, K., Jones, J.R., and Perkins, B.D., 1992, Effects of nutrient enrichment and flood frequency on periphyton biomass in northern Ozark streams: Canadian Journal of Fisheries and Aquatic Sciences, v. 49, p. 1,198-1,205.

Maddock, I., 1999, The importance of physical habitat assessment for evaluating river health: Freshwater Biology, v. 41, p. 373-391.

Magurran, A.E., 1988, Ecological diversity and its measurement: New Jersey, Princeton University Press, $179 \mathrm{p}$. 
Maret, T.R., 1997, Characteristics of fish assemblages and related environmental variables for streams of the upper Snake River Basin, Idaho and Western Wyoming, 1993-95: U.S. Geological Survey Water-Resources Investigations Report 97-4087, 50 p. [Also available at http://pubs.usgs. gov/wri/1997/4087/report.pdf.]

Maret, T.R., MacCoy, D.E., Skinner, K.D., Moore, S.E., and O'Dell, I., 2001, Evaluation of macroinvetebrate assemblages in Idaho Rivers using multimetric and multivariate techniques, 1996-98: U.S. Geological Survey Scientific Investigations Report 2001-4145, 69 p. [Also available at http://pubs.er.usgs.gov/publication/wri014145.]

Maret, T.R., Robinson, C.T., and Minshall, G.W, 1997, Fish assemblages and environmental correlates in least-disturbed streams of the Upper Snake River: Transactions of the American Fisheries Society, v. 123, no. 2, p. 200-216.

McCabe, D.J., and Gotelli, N.J., 2000, Effects of disturbance frequency, intensity, and area on assemblages of stream invertebrates: Oecologia, v. 124, p. 270-279.

McCabe, G.J., and Clark, M.P., 2005, Trends and variability in snowmelt runoff in the western United States: Journal of Hydrometeorology, v. 6, p. 476-482, accessed September 17, 2015, at http://journals.ametsoc.org/doi/abs/10.1175/ JHM428.1.

McGrath, C.L., Woods, A.J., Omernik, J.M., Bryce, S.A., Edmondson, M., Nesser, J.A., Shelden, J., Crawford, R.C., Comstock, J.A., and Plocher, M.D., 2002, Ecoregions of Idaho (color poster with map, descriptive text, summary tables, and photographs): Reston, Virginia, U.S. Geological Survey (map scale 1:1,350,000), accessed April 15, 2016, at https://archive.epa.gov/wed/ecoregions/web/html/id_eco. html.

Mebane, C.A., Maret, T.R., and Hughes, R.M., 2003, An index of biological integrity (IBI) for Pacific Northwest Rivers: Transactions of the American Fisheries Society, v. 132, no. 2, p. 239-261.

Meyer, K.A., Cassinelli, J.D., and Elle, F.S., 2008, Life history characteristics of the Wood River Sculpin, Cottus leiopomus (Cottidae), in Idaho: American Society of Ichthyologists and Herpetologists, p. 648-655, accessed June 25, 2015, at http://www.bioone.org/doi/full/10.1643/CI-07-137.

Miller, M., Iverson, E., and Essig, D., 2014, Geography and timing of salmonid spawning in Idaho: Boise, Prepared for Idaho Department of Environmental Quality, 47 p., accessed August 24, 2015, at http://www.deq.idaho.gov/waterquality/surface-water/temperature/.

Monk, W.A., Wood, P.J., Hannah, D.M., and Wilson, D.A., 2008, Macroinvertebrate community response to interannual and regional river-flow regime dynamics: River Research and Applications, v. 24, p. 988-1,001.
Moulton, S.R., II, Kennen, J.G., Goldstein, R.M., and Hambrook, J.A., 2002, Revised protocols for sampling algal, macroinvertebrate, and fish communities as part of the National Water-Quality Assessment Program: U.S. Geological Survey Open-File Report 02-150, 75 p., http:// pubs.usgs.gov/of/2002/ofr-02-150/.

Mueller, D.S., and Wagner, C.R., 2009, Measuring discharge with acoustic Doppler current profilers from a moving boat: U.S. Geological Survey Techniques and Methods book 3, chap. A22, 72 p., http://pubs.water.usgs.gov/tm3a22.

Munn, M., Frey, J., and Tesoriero, A., 2010, The influence of nutrients and physical habitat in regulating algal biomass in agricultural streams: Environmental Management, v. 45, p. 603-615.

Naiman, R.J., Latterell, J.J., Pettit, N.E., and Olden, J.D., 2008 , Flow variability and the biophysical vitality of river systems: Comptes Rendus Geoscience, v. 340, p. 629-643.

Olden, J.D., and Poff, N.L., 2003, Redundancy and the choice of hydrologic indices for characterizing streamflow regimes: River Research and Applications, v. 19, p. 101-121.

Omernik, J., and Griffith, G., 2008, Ecoregions of the Continental United States-Level IV: U.S. Environmental Protection Agency, accessed July 21, 2016, at https:// archive.epa.gov/wed/ecoregions/web/html/level_iii_iv-2. html.

Patton, C.J., and Kryskalla, J.R., 2003, Methods of analysis by the U.S. Geological Survey National Water-Quality Laboratory-Evaluation of alkaline persulfate digestion as an alternative to Kjeldahl digestion for determination of total and dissolved nitrogen and phosphorus in water: U.S. Geological Survey Water-Resources Investigations Report 03-4174, 33 p., accessed July 28, 2015, at http://nwql.usgs. gov/Public/rpt.shtml?WRIR-03-4174.

Patton, C.J., and Kryskalla, J.R., 2011, Colorimetric determination of nitrate plus nitrite in water by enzymatic reduction, automated discrete analyzer methods: U.S. Geological Survey Techniques and Methods, book 5, chap. B8, 34 p.

Peipoch, M., Brauns, M., Hauer, F.R., Weitere, M., and Valett, H.M., 2015, Ecological simplification-Human influences on riverscape complexity: BioScience, v. 65, p. $1,057-1,065$.

Penaluna, B.E., Dunham, J.B., and Noakes, D.L.G., 2015, Instream cover and shade mediate avian predation on trout in semi-natural streams: Ecology of Freshwater Fish, v. 25, no. 3, p. 405-411, accessed February 22, 2016, at http:// onlinelibrary.wiley.com/doi/10.1111/eff.12221/epdf. 
Pentzer, C., 2006, Big Wood watershed total maximum daily load (TMDL) - Implementation plan for agriculture: Idaho Department of Environmental Quality, 68 p., accessed June 2, 2015, at http://www.deq.idaho.gov/big-wood-riversubbasin.

Pepin, D.M., and Hauer, F.R., 2002, Benthic responses to groundwater-surface water exchange in 2 alluvial rivers in northwestern Montana: Journal of the North American Benthological Society, v. 21, p. 370-383.

Petts, G.E., and Maddock, I., 1997, Flow allocation for in-river needs, in Petts, G.E. and Calow, P., eds., River restoration: London, Blackwell Science, Ltd., p. 60-79.

Platts, W.S., Amour, C., Booth, G.D., Bryant, M., Buford, J.L., Culpin, P., Jensen, S., Lienkaemper, G.W., Minshall, W.G., Monsen, S.B., Nelson, R.L., Sedell, J.R., and Tuhy, J.S., 1987, Methods for evaluating riparian habitats with applications to management: Ogden, Utah, U.S. Forest Service General Technical Report INT-138, 177 p.

Poff, L.N., Allan, J.D., Bain, M.B., Karr, J.R., Prestegaard, K.L., Richter, B.D., Sparks, R.E., and Stromberg, J.C., 1997, The natural flow regime-A paradigm for river conservation and restoration: Bioscience, v. 47 , no. 11 , p. 769-784.

Pritt, J.W., and Raese, J.W., eds., 1995, Quality assurance/ quality control manual-National Water-Quality Laboratory: U.S. Geological Survey Open-File Report 95-443, 35 p.

Rantz, S.E., and others, 1982, Measurement and computation of streamflow: U.S. Geological Survey Water-Supply Paper 2175, v. 2, 631 p., [Also available at http://pubs.usgs.gov/ wsp/wsp2175/html/wsp2175_vol2.html.]

Relyea, C.D., Minshall, G.W., and Danehy, R.J., 2012, Development and validation of an aquatic fine sediment biotic index: Environmental Management, v. 49, p. 242-252.

Renk, Russ, 1986, Impacts of geothermal waters on selected streams in southern Idaho: Boise, Idaho Department of Health and Welfare, Division of Environment, Waterquality Status Report No. 60, 13 p., plus 2 appendixes, accessed October 23, 2012, at http://www.deq.idaho.gov/ media/435172-wqs60_geothermal_waters_1986.pdf.

Resh, V.H., Brown, A.V., Covich, A.P., Gurtz, M.E., Li, H.W., Minshall, G.W., Reice, S.R., Sheldon, A.L., Wallace, J.B., and Wissmar, R.C., 1988, The role of disturbance in stream ecology, community structure and function in temperate and tropical streams - Proceedings of a symposium: Journal of the North American Benthological Society, v. 7, no. 4, p. $433-455$.
Richards, D.C., Bilger, M., and Lester, G., 2013, Development of Idaho macroinvertebrate temperature occurrence models: Moscow, Idaho, EcoAnalysts, 72 p., accessed April 5, 2016, at http://www.deq.idaho.gov/media/60177748/developmentidaho-macroinvertebrate-temperature-occurrence-models. pdf.

Riseng, C.M., Wiley, M.J., Black, R.W., and Munn, M.D., 2011, Impacts of agricultural land use on biological integrity-A causal analysis: Ecological Applications, v. 21, p. $3,128-3,146$.

Rosenfeld, J., 2003, Assessing the habitat requirements of stream fishes-An overview and evaluation of different approaches: Transactions of the American Fisheries Society, v. 132 , p. $953-968$.

Sheldon, F., and Thoms, M.C., 2006, Relationships between flow variability and macroinvertebrate assemblage composition - Data from four Australian dryland rivers: River Research Applications, v. 22, p. 219-238.

Skinner, K.D., 2013, Post-fire debris-flow hazard assessment of the area burned by the 2013 Beaver Creek Fire near Hailey, central Idaho: U.S. Geological Survey Open-File Report 2013-1273, 12 p., 9 pls. [Also available at http:// dx.doi.org/10.3133/ofr20131273.]

Skinner, K.D., Bartolino, J.R., and Tranmer, A.W., 2007, Water-resource trends and comparisons between partial development and October 2006 hydrologic conditions, Wood River Valley, south-central, Idaho: U.S. Geological Survey Scientific Investigations Report 2007-5258, 30 p. [Also available at http://pubs.usgs.gov/sir/2007/5258/index. html.]

Stewart, I.R., Cayan, D.R., and Dettinger, M.D., 2004, Changes in snowmelt runoff timing in western North America under a "business as usual" climate change scenario: Climate Change, v. 62, p. 217-232.

Tetra Tech, 2011, Biological assessment frameworks and index development for rivers and streams in Idaho: Tetra Tech, prepared for the Idaho Department of Environmental Quality, 229 p., accessed July 27, 2015, at http://www. deq.idaho.gov/media/756703-biological_assessment frameworks_index_development_rivers_streams_0411.pdf.

Thurow, R.F., 1988, Effects of stream alterations on rainbow trout in the Big Wood River, Idaho: 68th Annual Conference of the Western Association of Fish and Wildlife Agencies, http://db.lib.uidaho.edu/FG/Vol/079/Article_12.pdf.

Townsend, C.R., Scarsbrook, M.R., and Doledec, S., 1997, The intermediate disturbance hypothesis, refugia, and biodiversity in streams: Limnology and Oceanography, v. 42 , p. $938-949$. 
Turnipseed, D.P., and Sauer, V.B., 2010, Discharge measurements at gaging stations: U.S. Geological Survey Techniques and Methods, book 3, chap. A8, 87 p., http:// pubs.usgs.gov/tm/tm3-a8/.

U.S. Census Bureau, 2011, State and county Quickfacts, Blaine County, Idaho: U.S. Census Bureau database, accessed July 27, 2015, at http://quickfacts.census.gov/qfd/ states/16/16013.html.

U.S. Environmental Protection Agency, 2006, Wadeable streams assessment-A collaborative survey of the Nation's streams: U.S. Environmental Protection Agency, Office of Research and Development and Office of Water, EPA841-B-06-002, 98 p.

U.S. Environmental Protection Agency, 2012, Primer for identifying cold-water refuges to protect and restore thermal diversity in riverine landscapes: U.S. Environmental Protection Agency, $91 \mathrm{p}$.

U.S. Geological Survey, 2016a, WaterWatch-Idaho: U.S. Geological Survey data base, http://waterwatch.usgs.gov/

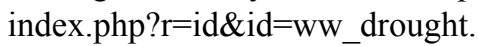

U.S. Geological Survey, 2016b, Biodata-Aquatic bioassessment data for the Nation: U.S. Geological Survey Web site, accessed July 27, 2016, at https://aquatic.biodata. usgs.gov/landing.action.

U.S. Geological Survey, 2016c, "Fish on"-Line-A Webaccessible database of aquatic biological data: U.S. Geological Survey Web site, accessed July 27, 2016, at http://greatbasin.wr.usgs.gov/fish/.

U.S. Geological Survey, 2016d, Streamstats: U.S. Geological Survey Web application, accessed April 15, 2016, at http:// water.usgs.gov/osw/streamstats/.

U.S. Geological Survey, 2016e, USGS water-data site information for Idaho: U.S. Geological Survey data base, April 15, 2016, at http://waterdata.usgs.gov/id/nwis/si.

U.S. Geological Survey, 2016f, The branch of quality systems: U.S. Geological Survey Web site, accessed April 15, 2016, at https://bqs.usgs.gov/.

U.S. Geological Survey, variously dated, National field manual for the collection of water-quality data: U.S. Geological Survey Techniques of Water-Resources Investigations, book 9, chaps. A1-A9, variously paged. [Also available at http:// water.usgs.gov/owq/FieldManual/.]

Wagner, R.J., Boulger, R.W., Fr., Oblinger, C.J., and Smith, B.A., 2006, Guidelines and standard procedures for continuous water-quality monitors-Station operation, record computation, and data reporting: U.S. Geological Survey Techniques and Methods, book 1, chap. D3, $51 \mathrm{p}$. plus 8 attachments, accessed July 28, 2015, at http://pubs. water.usgs.gov/tm1d3.
Ward, J.R., and Harr, C.A., 1990, Methods for collection and processing of surface-water and bed material samples for physical and chemical analysis: U.S. Geological Survey Open-File Report 90-140, 71 p. [Also available at http:// pubs.usgs.gov/of/1990/0140/report.pdf.]

Ward, J.V., 1992, Aquatic insect ecology I-Biology and habitat: New York, John Wiley \& Sons, 438 p.

Waters, T.F., 1995, Sediment in streams-Sources, biological effects, and control: Bethesda, Maryland, American Fisheries Society Monograph, v. 7, 251 p.

Whittier, T.R., Hughes, R.M., Stoddard, J.L., Lomnicky, G., Peck, D.V., and Herlihy, A.T., 2007, Three indices of biotic integrity for western USA streams and rivers-A structured approach to index development: Transactions of the American Fisheries Society, v. 136, p. 718-735.

Williams, J.E., 2000, The coefficient of condition of fish, in Schneider, J., and James, C., eds., Manual of fisheries survey methods II-With periodic updates: Ann Arbor, Michigan Department of Natural Resources, Fisheries Special Report 25, chap. 13, p. 1-2.

Wolman, M.G., 1954, A method of sampling coarse river-bed material: Transactions-American Geophysical Union, v. 35 , p. $951-956$.

Wood, M.S., Fosness, R.L., Skinner, K.D., and Veilleux, A.G., 2016, Estimating peak-flow frequency statistics for selected gaged and ungaged sites in naturally flowing streams and rivers in Idaho: U.S. Geological Survey Scientific Investigations Report 2016-5083, 56 p. [Also available at https://pubs.er.usgs.gov/publication/sir20165083.]

Zaroban, D.W., 2010, Considerations for Wood River Sculpin Conservation-Historical occurrence and sampling efficiency: Western North American Naturalist, v. 70, no. 4, p. 446-456.

Zuellig, R.E., Bruce, J.F., Evans, E.E., and Stogner, R.W., 2007, Urban-related environmental variables and their relation with patterns in biological community structure in the Fountain Creek Basin, Colorado, 2003-2005: U.S. Geological Survey Scientific Investigations Report 2007-5225, 24 p. [Also available at http://pubs.usgs.gov/ $\operatorname{sir} / 2007 / 5225 /$. 


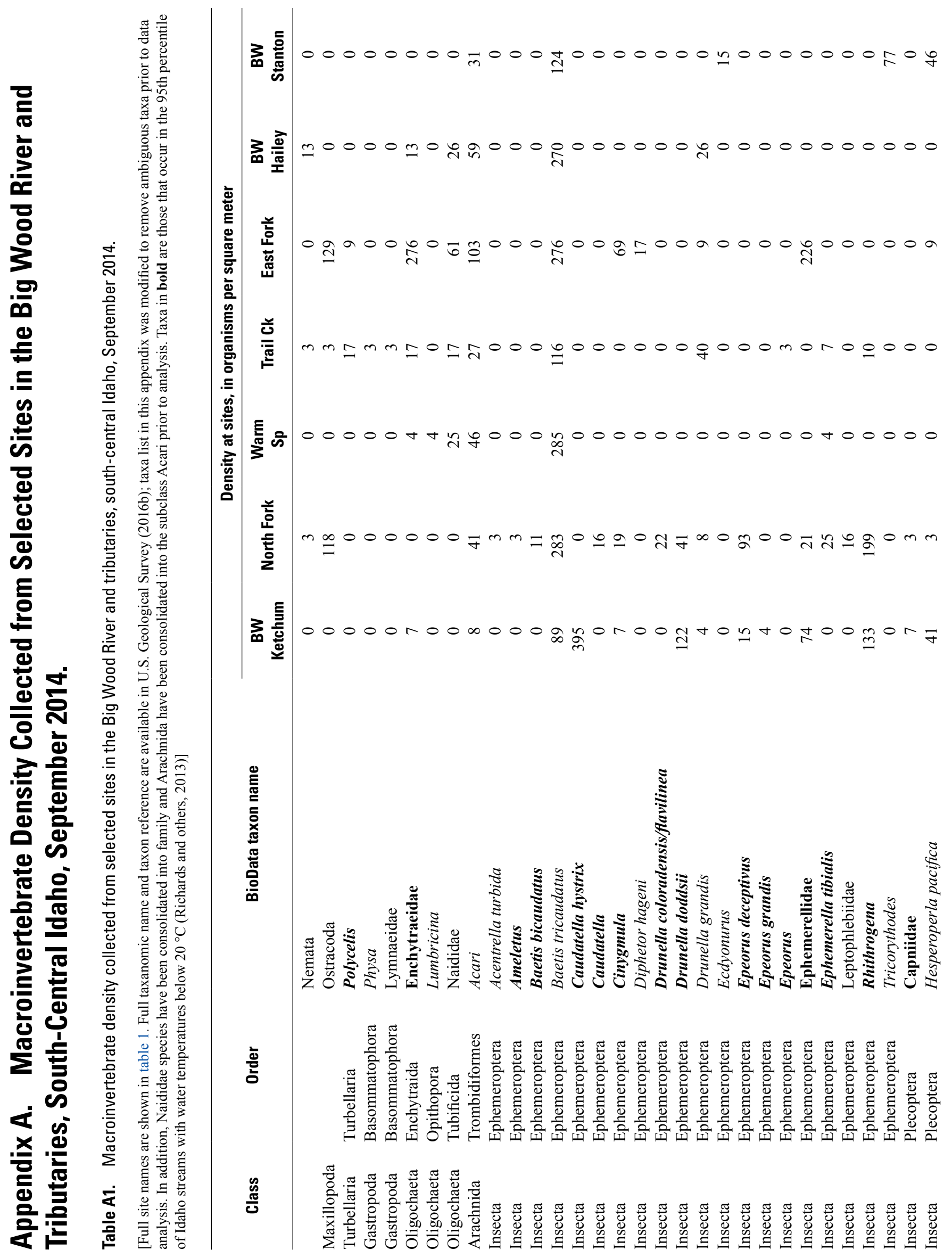




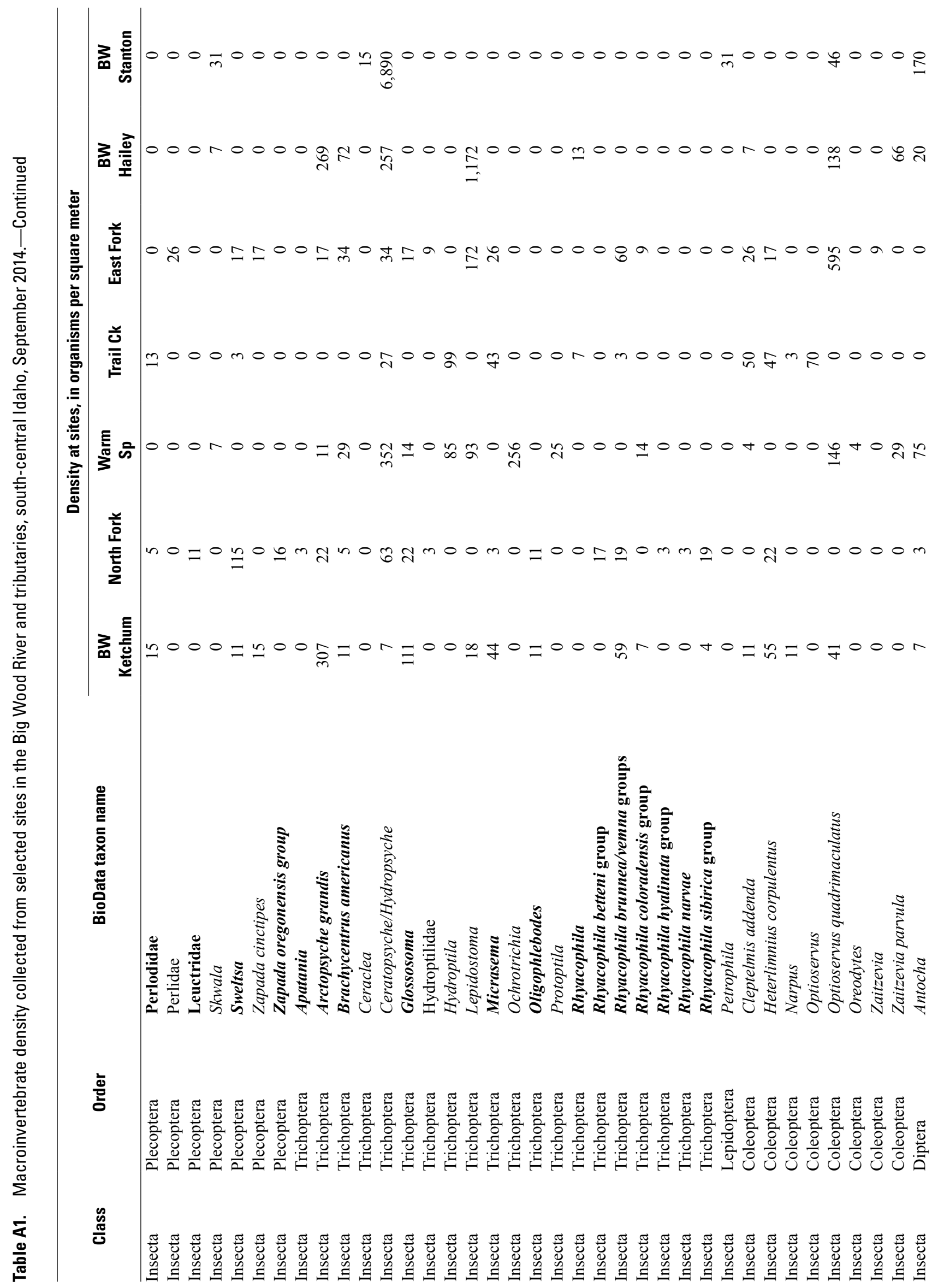




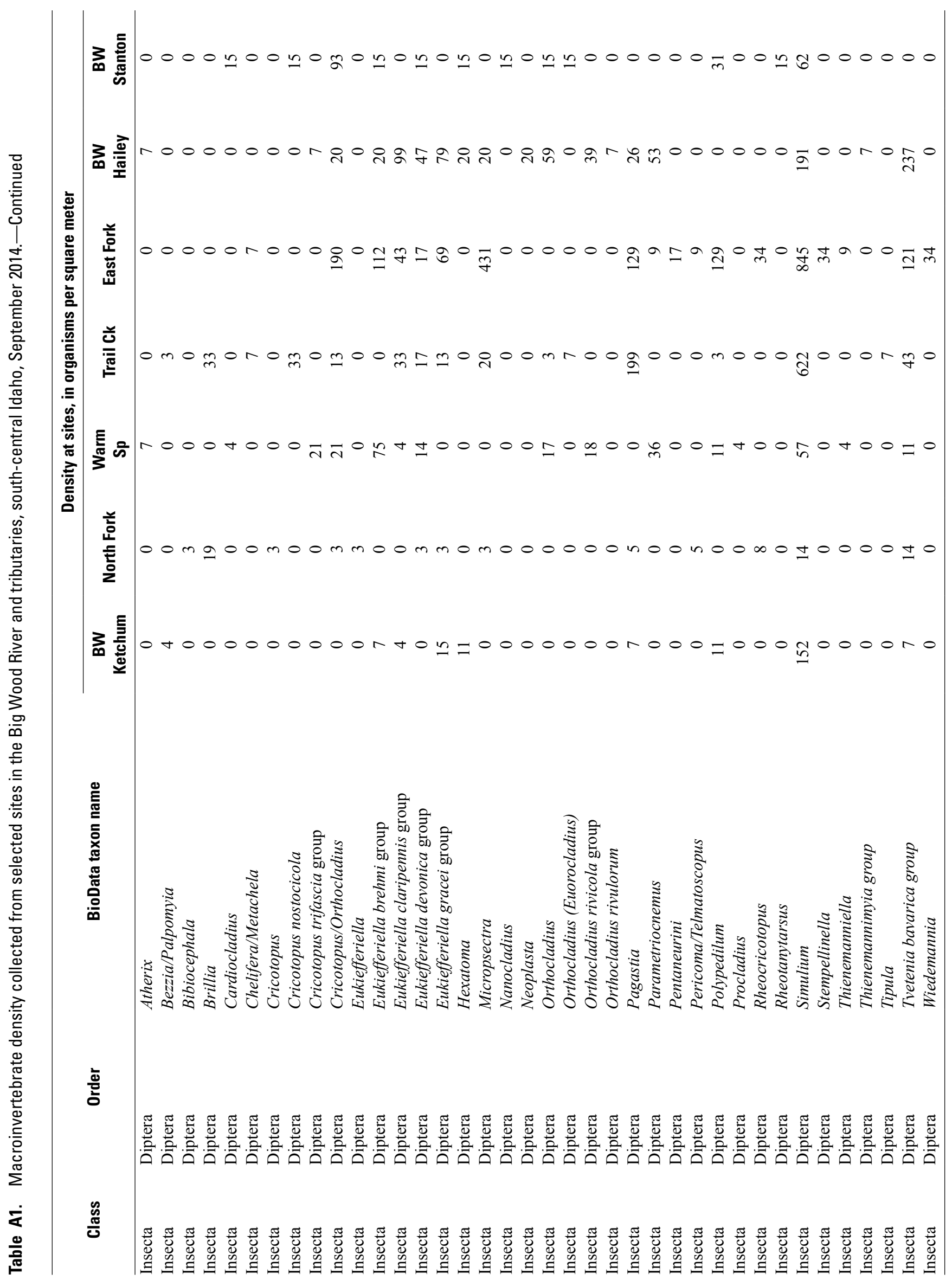




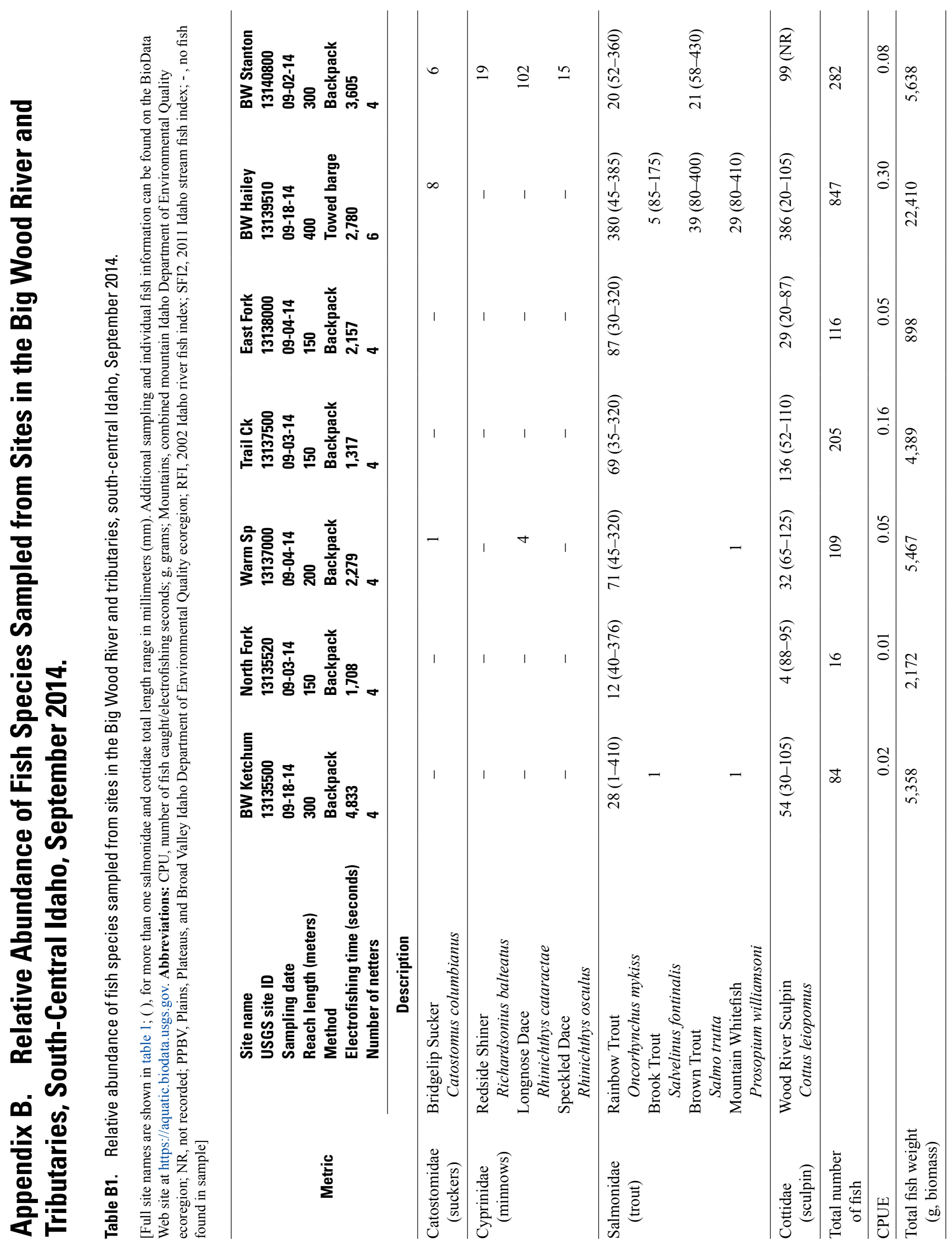




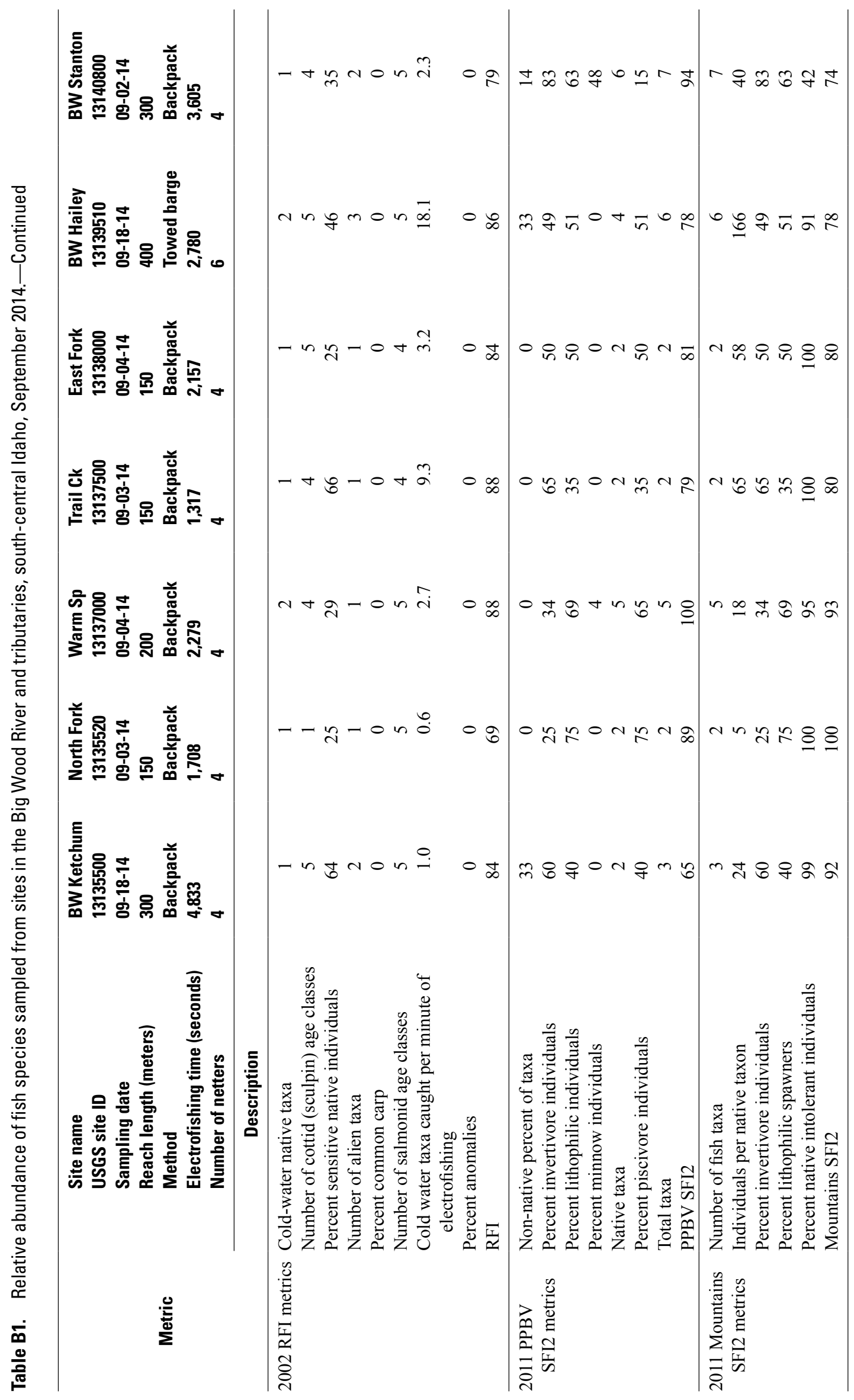



Publishing support provided by the U.S. Geological Survey Science Publishing Network, Tacoma Publishing Service Center

For more information concerning the research in this report, contact the Director, Idaho Water Science Center

U.S. Geological Survey

230 Collins Road

Boise, Idaho 83702

http://id.water.usgs.gov 
